\title{
Water-Saving Agricultural Technologies: Regional Hydrology Outcomes and Knowledge Gaps in the Eastern Gangetic Plains-A Review
}

\author{
Mohammad A. Mojid ${ }^{1, *(1)}$ and Mohammed Mainuddin ${ }^{2}$ (D) \\ 1 Department of Irrigation and Water Management, Bangladesh Agricultural University, \\ Mymensingh 2022, Bangladesh \\ 2 CSIRO Land and Water, Black Mountain Science and Innovation Park, Canberra, ACT 2601, Australia; \\ mohammed.mainuddin@csiro.au \\ * Correspondence: ma_mojid@bau.edu.bd
}

Citation: Mojid, M.A.; Mainuddin, M. Water-Saving Agricultural Technologies: Regional Hydrology Outcomes and Knowledge Gaps in the Eastern Gangetic Plains-A Review. Water 2021, 13, 636. https:/ / doi.org/10.3390/w13050636

Academic Editor: Fernando António Leal Pacheco

Received: 6 January 2021

Accepted: 19 February 2021

Published: 27 February 2021

Publisher's Note: MDPI stays neutral with regard to jurisdictional claims in published maps and institutional affiliations.

Copyright: (C) 2021 by the authors. Licensee MDPI, Basel, Switzerland. This article is an open access article distributed under the terms and conditions of the Creative Commons Attribution (CC BY) license (https:// creativecommons.org/licenses/by/ $4.0 /)$.

\begin{abstract}
Increasing food demand has exerted tremendous stress on agricultural water usages worldwide, often with a threat to sustainability in agricultural production and, hence, food security. Various resource-conservation technologies like conservation agriculture (CA) and water-saving measures are being increasingly adopted to overcome these problems. While these technologies provide some short- and long-term benefits of reduced labor costs, stabilized or increased crop yield, increased water productivity, and improved soil health at farm scale, their overall impacts on hydrology outcomes remain unclear at larger temporal and spatial scales. Although directly linked to the regional hydrological cycle, irrigation remains a less understood component. The ecological conditions arising from the hydrology outcomes of resource-conservation technologies are associated with sustainability in agricultural production. In this paper, the philosophies and benefits of resource-conservation technologies and expert perceptions on their impacts on temporal and spatial scales have been reviewed comprehensively focusing on regional hydrology outcomes in the Eastern Gangetic Plain (EGP). Due to data inadequacy and lack of knowledge-sharing among disciplines, little is yet known about actual water saving by these resource-conservation technologies and the level of their contribution in groundwater and surface water storage over large temporal and spatial scales. Inadequate knowledge of the hydrological effects of water applied in the agricultural field leads to the implementation of water management policy based on local perspectives only, often with the possibility of deteriorating the water-scarcity situation. Therefore, multidisciplinary future research should quantify regional hydrology outcomes by measuring the components of regional water balance in order to develop a proper water management policy for sustainable agricultural production.
\end{abstract}

Keywords: irrigation management; rice; percolation; scale effects; hydrologic cycle

\section{Introduction}

The global demand for food, energy and water by the ever-growing population has been forecasted to increase by 50\%,50\% and 30\%, respectively, in 2030 compared to 2012 [1]; in the same base period, food demand will increase by $70 \%$ to $100 \%$ by 2050 [2]. The Indo-Gangetic Plains (IGP) comprising more than 250 Mha of area across Bangladesh, India, Pakistan and southern Nepal have over 100 Mha of agricultural land and host over 750 million people [3]. The Lower Gangetic Plain, called the Eastern Gangetic Plain (EGP), comprises the adjoining states of Bihar and northern West Bengal in North-eastern India, the North-West of Bangladesh and the Terai plains of Nepal (Figure 1). The EGP is characterized by the world's highest density of rural poor, persistent yield gaps, low agricultural productivity, limited crop diversification, ample water resources [4,5], and highly fertile lands [6,7] of agricultural importance [8]. The region is therefore a global priority for sustainably increasing food production [9]. 


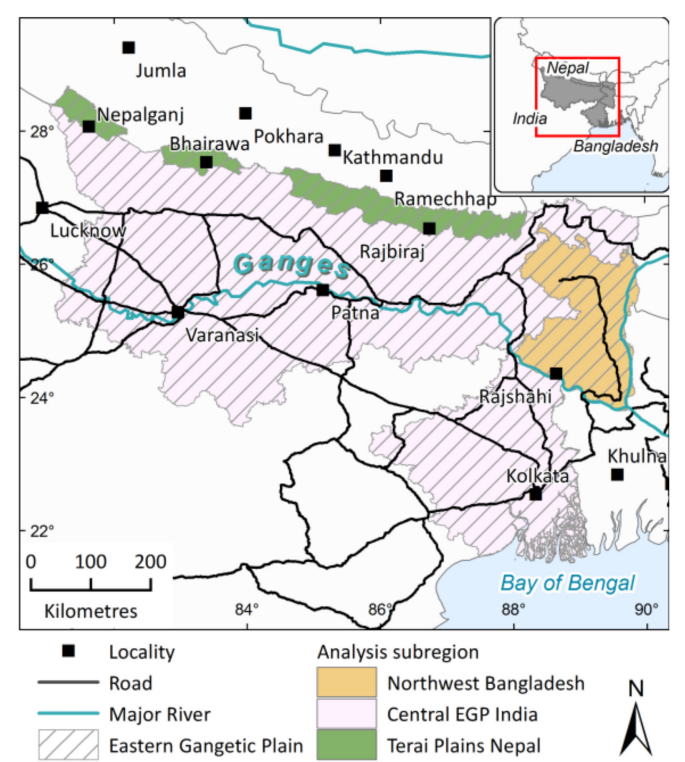

Figure 1. Location and area map of the Eastern Gangetic Plain (EGP) region.

Agricultural productivity is critically dependent on the availability of water. Adequate water supply significantly increases crop productivity [10,11] by introducing high yielding crop varieties, a better cropping pattern, and increasing cropping intensity [12]. Compared to rain-fed agriculture, irrigated agriculture produces two to four times more crop yields [13]. This contribution of irrigation increased global irrigated land by $76 \%$ between 1970 and 2012 [14]; the reliance of agricultural production on irrigation is expected to further increase in the future [15]. Farmers' capacity to access and use water is a major driving factor in obtaining the best yield and hence is an important variable for the food security index [16]. However, the growing competition for water by various sectors will affect farmers' ability to produce food $[17,18]$. So, making food production sustainable, while conserving diminishing water supplies, will be a great challenge in the future [19].

The Ganges basin has a tropical climate, with a distinct wet monsoon (June-September) and a dry winter (November-February); the summer is characteristically hot and humid. Except for the East and North-East hilly regions of the basin where annual rainfall often exceeds $4000 \mathrm{~mm}$, the average annual rainfall in most other parts is $1500 \mathrm{~mm}$. The rainfall is mostly concentrated in the monsoon season and the winter is almost rainless [20] but the main cropping season. In many parts of the IGP, agricultural drought and other climatic shocks severely affect crop production, thus, necessitating an adequate water supply to stabilize agricultural production [21,22]. Surface water is inadequate in the dry season, but groundwater plays a vital role in sustaining agricultural productivity. In India, $60 \%$ of the agricultural water requirement is satisfied from groundwater, covering over $50 \%$ of the irrigated area [23]; in Bangladesh, the corresponding quantities are $79 \%$ and $85 \%$ [24]. Of the many factors now threatening sustainability in agricultural productivity, water is the most crucial [25-33] since, without further improvement in water productivity, the amount of water needed for crop agriculture is predicted to increase by $70-90 \%$ by 2050 [34].

Several resource-conservation technologies like minimum tillage, no/zero-tillage, direct-seeding, bed-planting, laser land-leveling and residue retention [35-37], and watersaving technologies like alternate wetting and drying (AWD) and deficit irrigation methods have been developed over the past three decades and are being practiced in many parts of the world, including the EGP. In addition to the benefits from the conserved resources, these technologies can also change crop-water use and the regional water cycle [38] with negative impact on groundwater dynamics [39]. They save water by reducing water application in the fields, with resulting lower percolation and groundwater recharge. Large-scale adoption of these technologies can therefore lead to significant decline in groundwater levels [40-42], with possible degradation of soil quality and damage of vegetation [43]. In 
many parts of the EGP, groundwater level has declined significantly, and is now threatening sustainable water supply for irrigation and drinking [44-49] with resulting negative impacts on the economy, society and environment [50-53]. Although less than one-third of the IGP has experienced declining groundwater levels [54] the situations in high-population centers (e.g., Dhaka city) and other stressed areas (e.g., the Barind area) are potentially alarming [49].

Agriculture in the IGP is mostly dominated by irrigated rice-wheat systems, which cover 13.5 Mha and play a crucial role in the food security and livelihoods of millions of people $[37,55,56]$. In Bangladesh and West Bengal, rice is produced on 6.05 Mha and 5.5 Mha, respectively [57]. Both mechanized and tillage-based traditional agriculture and transplanted rice cultivation with flood irrigation requiring a huge quantity of water [58-60] are a major challenge in agriculture, in order to maintain or increase rice production. Shifting current agriculture to water-efficient ones [61-65] would conserve water from being wasted through unintended purposes and make considerable water savings [66-69] to face the challenge. Conversion of conventional agriculture to resource-conservation methods [70-72] using resource-conservation technologies and water-saving measures has been demonstrated as of particular interest in this regard [29,73-76].

When water is applied in a crop field, not all of it is consumed as illustrated in Figure 2. The local surface and sub-surface hydrological systems retain a considerable portion of the applied water, which might be reusable later by other users. Consequently, irrigation has a direct link to the regional hydrological cycle, especially in areas with shallow groundwater [54]. A large part of the applied irrigation water infiltrates below the root zone and is stored in the underlying aquifer $[7,43]$ or in downstream surface water bodies. Figure 3 conceptualizes the flow paths of the components of water from a rice field under conventional flood irrigation with pumped groundwater. The percolated water is perceived as lost by the farmers and irrigation practitioners [77] but is a gain to the local surface and sub-surface hydrological systems. The efficiency of water usage at any separate component (e.g., crop fields, ponds) within the hydrological system may be low, but the overall efficiency of the entire system can be much higher than in the individual components. So, the general concept of water use efficiency undervalues the real efficiency of the whole hydrological system. Water recycling must be integrated into the concept of water-use efficiency to develop new realistic concepts [78]. The water flux exchanging between the aquifer and vadoze zone greatly controls the dynamics of the groundwater table [39] thus raising a valid question of how the currently advocated water-saving measures impact on the hydrological cycle of a groundwater basin. Do these water-saving measures assure proper utilization of groundwater reserves? In situations where downstream aquifers and surface water bodies are fed from upstream aquifers, what will be the effects of the water-saving measures on these downstream water resources (Figure 3)? These important issues have not yet been investigated critically on the system level; only some field-scale studies have investigated the possibilities, which are also contrasting in nature. A summary of the major previous studies assessing the impacts of various agricultural water-saving technologies on local and regional hydrology is presented in Table 1. In light of this short-coming, this paper comprehensively reviewed the available literature to evaluate the present state of knowledge and emerging knowledge-gaps on this subject so as to guide future research on this topic. Note that since rice-based cropping systems dominate the agricultural landscape of the EGP [56], this study focuses on the exchange of water flux between irrigated rice fields and the underlying aquifers. The paper is structured into five major sections in addition to an introduction and a concluding section. The benefits and impacts of conservation agriculture have been reviewed in the second section. The third section highlights the complementary and contemporary meanings of water saving while the fourth section addresses the impacts of agricultural water-saving methods on regional hydrology outcomes (i.e., links between various components of the regional hydrological cycle). The next section identifies current knowledge gaps in the 
key water-saving issues, including scale-effects and policy, before an overall summary and concluding section on water-saving measures and regional hydrology outcomes.

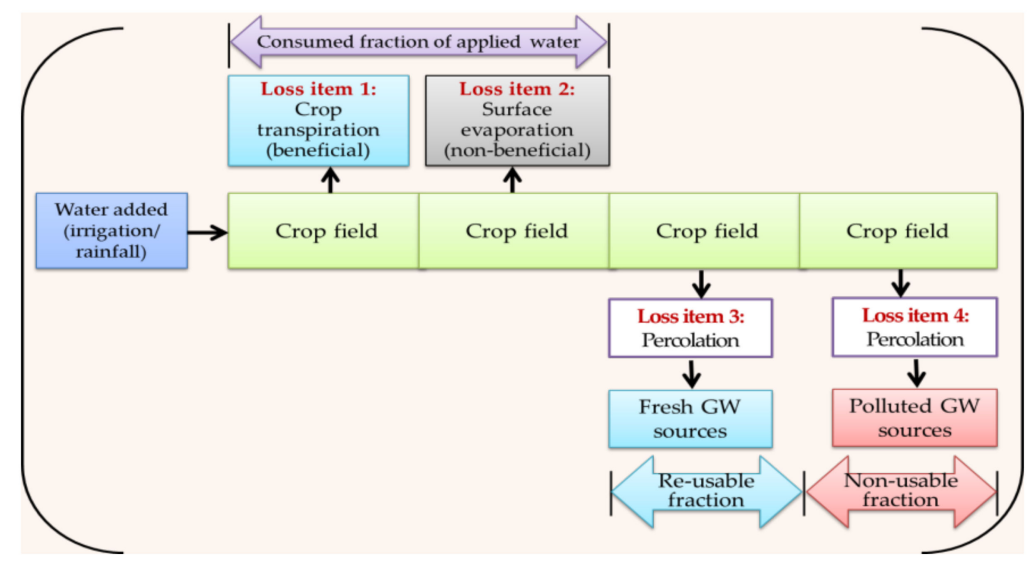

Figure 2. Utilization and fate of applied water to crop fields and hydrological links to groundwater resources.

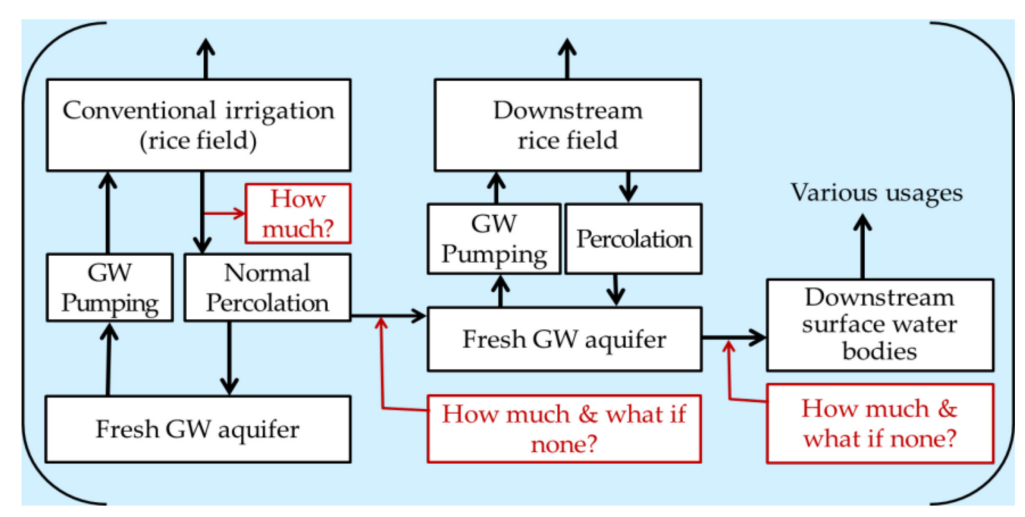

Figure 3. The pathways of the components of water from a rice field under conventional irrigation with groundwater.

\section{Conservation Agriculture}

\subsection{Philosophies and Benefits}

Conservation agriculture (CA) has been developed as a response to concerns about sustainability in agriculture [55,79-83] with basic principles of rebuilding soil, optimizing crop production inputs (resource and energy), enhancing food production and optimizing profits [84-87]. It comprises application of three inter-linked principles: (i) no or minimum mechanical soil disturbance through conservation tillage (e.g., minimum or zero-tillage), (ii) biomass mulch soil cover (e.g., crop residues), and (iii) crop diversification, as well as other practices of integrated crop management [88]. Under conservation tillage, approximately $30 \%$ of the soil surface is kept covered with crop residues, which reduces erosion of surface soil by overland flow [89,90]; a crop is planted directly into a seedbed without any tillage operation in the zero-tillage system. Cultivation of wheat under zero-tillage in the ricewheat cropping system is an emerging CA-based technology in the IGP [91]. A CA-based sustainable intensification program was started in 2014-15 in two districts each of Nepal, Bangladesh, and Bihar and West Bengal in India [92]. Globally, the cropland under CA increased at 5.3 Mha annually since 1990 and reached 106 Mha in 2008/2009 [93] and 180 Mha in 2015/2016; 78 countries in the world have adopted CA practices. 
Table 1. Summary of major previous studies assessing the impacts of agricultural water-saving technologies on local and regional hydrology. The studies are grouped by apparent and actual water saving, impacts of water-saving measures on water usage and regional water balance, gaps in current knowledge in certainty and scale-effect of water saving, and policy formulation for water resources management.

\begin{tabular}{|c|c|}
\hline Main Findings & References \\
\hline \multicolumn{2}{|l|}{ Apparent and actual water saving } \\
\hline $\begin{array}{l}\text { Water-saving technologies make only narrowly perceived local water } \\
\text { saving without considering irrigation return flows. }\end{array}$ & {$[94,95]$} \\
\hline $\begin{array}{l}\text { Percolation from irrigated fields recharges the underlying aquifer in } \\
\text { many groundwater basins, including the IGP basin, from where it is } \\
\text { recoverable for reuse; so is not a loss. }\end{array}$ & {$[54,96-102]$} \\
\hline $\begin{array}{l}\text { Water-saving by one user may be a loss to another over large spatial } \\
\text { scale. So, reducing percolation does not always save water. }\end{array}$ & {$[75,95,103,104]$} \\
\hline $\begin{array}{l}\text { Reduction in evaporation and water-flows to non-recoverable sinks } \\
\text { (e.g., polluted water sources) makes actual water saving. }\end{array}$ & [105-107] \\
\hline \multicolumn{2}{|l|}{ Impacts of water-saving measures on water usage } \\
\hline $\begin{array}{l}\text { Alternate wetting and drying (AWD) water management method saves } \\
\text { between } 15 \% \text { and } 60 \% \text { of water compared to continuous standing } \\
\text { water rice system. }\end{array}$ & {$[60,108-112]$} \\
\hline $\begin{array}{l}\text { Demand for water increases when technological intervention adds } \\
\text { more value to it (e.g., reduced cost of water due to increased irrigation } \\
\text { efficiency); this is the re-bound effect. }\end{array}$ & {$[75,113-116]$} \\
\hline $\begin{array}{l}\text { Re-bound effect is a potential hindrance in water } \\
\text { resource management. }\end{array}$ & [117] \\
\hline
\end{tabular}

Impacts of water-saving measures on regional water balance

Water-saving measures over regional scales cause decline in groundwater level by limiting recharge and exert stress on regional hydrology and ecology.

Most rivers and aquifer systems are hydraulically connected in Bangladesh and the Bengal Basin.

Separate management of surface and groundwater in the interconnected hydrologic systems hinders water resource allocation.

\begin{tabular}{l}
\multicolumn{2}{c}{ Knowledge gaps in certainty and scale-effect in water saving } \\
\hline $\begin{array}{l}\text { Impacts of water-saving technologies on the degree of actual } \\
\text { water-savings and overall water usage in groundwater-based irrigation }\end{array}$ \\
$\begin{array}{l}\text { systems are poorly understood at larger spatial scales. } \\
\text { The components of water balance in the Eastern Gangetic Plain (EGP) } \\
\text { basin have not been quantified yet. }\end{array} \quad[106,125]$ \\
$\begin{array}{l}\text { Focusing on only local efficiency of water use and ignoring the return } \\
\text { flows is a risky perception. }\end{array}$
\end{tabular}

\section{Knowledge gaps in formulating proper policy for water resources management}

Lack of attention, improper legislation and ineffective/less-effective institutions are the common problems in governing groundwater in many countries, especially in the face of re-bound effect.

Reliable detail information on water reserves, safe yield, water withdrawal patterns and water quality dynamics in the aquifers is lacking in most of the EGP basin.

Whether water-saving technologies can maintain sustainable development and what more need to be done for this in future remain uncertain.

Appropriate strategy for water management should be regionally suited and must establish strong regulation and policy. This is a topic of future research for the Indo-Gangetic Plains (IGP) basin. 
Resource-conservation technologies have revealed some promising immediate [135-137] and long-term benefits [138-140]. They reduce field-scale irrigation, fertilizer applications, labor shortages, energy use, greenhouse gas emission, and erosion of field soil; while they increase soil organic matter and biotic activity, crop diversification, yields, and farm incomes by improving resource-use efficiency [36,37,55,75,83,91,141-146]. Tillage accelerates oxidation of soil organic matter to $\mathrm{CO}_{2}$ and loss to the atmosphere, but CA reduces the oxidation rate $[147,148]$. Increased crop residues under CA and root exudation of carbon compounds into the soil cause a reversal of soil carbon from net loss to a net gain [86,149-151]. In spite of these multiple benefits [152-154] the farmers' prime interest in CA-based agriculture is mostly the monetary gain [155]. Nonetheless, CA is now emerging as a major component of farming systems for ensuring food security in South Asia [85,87].

\subsection{Impacts on Soil and Water Use}

The effects of conservation agriculture on soil properties vary depending on the type of chosen system, soil-type, climatic conditions, cropping history, etc. [156-158]. Soil becomes more stable and less susceptible to erosion under zero-tillage compared to conventional tillage $[158,159]$ and provides more satisfactory physical properties for crop production [160]. Soil organic carbon increases [92,161,162] and pH decreases [163] under zero-tillage compared to a conventional tillage system over time [164,165]. Organic matter improves soil aggregation, alters pore-size distribution, reduces soil bulk density, and increases both total and effective porosities within $0-5 \mathrm{~cm}$ soil profile [166,167]. The increased number of $0.5-50 \mu \mathrm{m}$ pores augments soil-water storage and 50-500 $\mu \mathrm{m}$ pores enhance water movement through the soil $[92,168]$. Conventional tillage creates a surface crust of high bulk density, while long-term (e.g., 8-10 years) zero-tillage helps in forming many continuous pores extending from the soil surface to the deeper layers causing significant increase in infiltration [161,166,169-171]. Zero-tillage thus increases the saturated and unsaturated hydraulic conductivity of soils $[159,162,172,173]$. Conservation tillage can increase the capture of rainfall and reduce runoff due to stable aggregates and increased porosity in the surface soil [174] and water-holding capacity due to increased organic matter [159] with resulting reduction in surface evaporation. The magnitudes of water-, labor- and energy-saving of some CA practices are listed in Table 2. However, generalization about such gains in water saving for all hydrological situations can provide a wrong message in many regions. In the dry season, there is not enough water on the soil surface to increase its capture in the soil within the EGP. There are only occasional relatively ample rainfall events in some areas of the EGP, in which cases CA can make more water available for plants use and increase the precipitation-use efficiency of the production system [166]. However, water is almost always in excess of soil's saturation capacity in the wet season, thus leaving no scope for further capturing of rainfall into the soil. The important controlling factors in conserving water in the wet season are the infiltration capacity and hydraulic conductivity of the soil. However, this likelihood has not yet been investigated.

Table 2. Degree of benefits of conservation agricultural (CA) practices.

\begin{tabular}{lccc}
\hline \multicolumn{1}{c}{ CA Practices } & Benefits & Magnitude & References \\
\hline Zero tillage/ laser land leveling/ & Water saving & $23-45 \%$ & {$[175]$} \\
bed and furrow planting & Water saving & $5-15 \%$ & {$[176]$} \\
Zero tillage & Water saving & $25 \%$ & {$[177]$} \\
Laser land leveling & Water saving & $10.6 \%$ & {$[178]$} \\
Permanent bed & Water saving & $21.8 \%$ & {$[178]$} \\
Zero-tillage & Labor saving & $40-45 \%$ & {$[179]$} \\
Direct-seeded rice & Water saving & $30-40 \%$ & {$[179]$} \\
Direct-seeded rice & Energy saving & $60-70 \%$ & {$[179]$} \\
Direct-seeded rice & & & \\
\hline
\end{tabular}




\section{Agricultural Water-Saving}

\subsection{Water-Saving Measures}

Water-saving irrigation, groundwater regulation, shifts to rain-fed agriculture, artificial recharge to groundwater, rainwater preservation, virtual water imports and indirect approaches like energy pricing and regulation are the currently available measures to reduce regional water use $[134,180]$. However, appropriate water-accounting is essential to identify the scope of these water-saving practices [181]. Based on the approach of reducing evaporation, runoff losses, and the extent of free water on the soil surface [182] irrigation strategies like shallow water depth associated with wetting and drying [183,184], alternate wetting and drying, AWD [108,124,185,186], semi-drying [187], aerobic rice cultivation [188,189], partial root-zone drying [190], and non-flooded mulching [191] are being practiced in different rice-growing regions. The AWD technique allows the soil to dry for a certain pre-determined number of days after depletion of the standing water in the field before the next irrigation [192]. The multiple-shallow irrigation method (1-3 cm irrigation applied frequently) can efficiently utilize rainfall and reduce percolation and surface runoff [94]. In the aerobic cultivation method, rice is grown in well-drained dry soils with supplementary irrigation, as with upland crops [188]. Furrow irrigation with raised beds, mulching, conservation tillage, deficit irrigation [193-195] and improved weed control can also achieve substantial water-saving.

\subsection{Apparent and Actual Water-Saving}

The impact of efficiency of water consumption and water productivity on watersaving has been investigated at field scale on several occasions e.g., [196-200]. Any effort toward improving irrigation efficiency is valuable [201], but the commonly used concepts of water-use efficiency underestimate the system-level's actual efficiency [78]. The actual fraction of the applied water that is used efficiently at a regional scale has not yet been quantified; current measurement methods are inadequate for such quantification.

All the water applied in the crop/rice fields ends up at any of, or a combination of, consumptive use, non-consumptive use, non-recoverable flow (Figure 2), and change in storage [95]. These water use-terms allow a clearer definition of various issues and options for water usage in irrigated agriculture. Water-saving through a resource-conservation technology refers to a narrow local perspective of water application by reducing percolation rates, as conceptualized in Figure 4. This water-saving does not account for return flows from the irrigated field that may be either non-recoverable outflow (e.g., to saline or otherwise polluted groundwater or surface water as schematized in Figure 5) or recoverable outflow, where it ends up in rivers or as useable groundwater source [94,95]. The return flow may be a significant contributor to groundwater recharge [131,202-204].

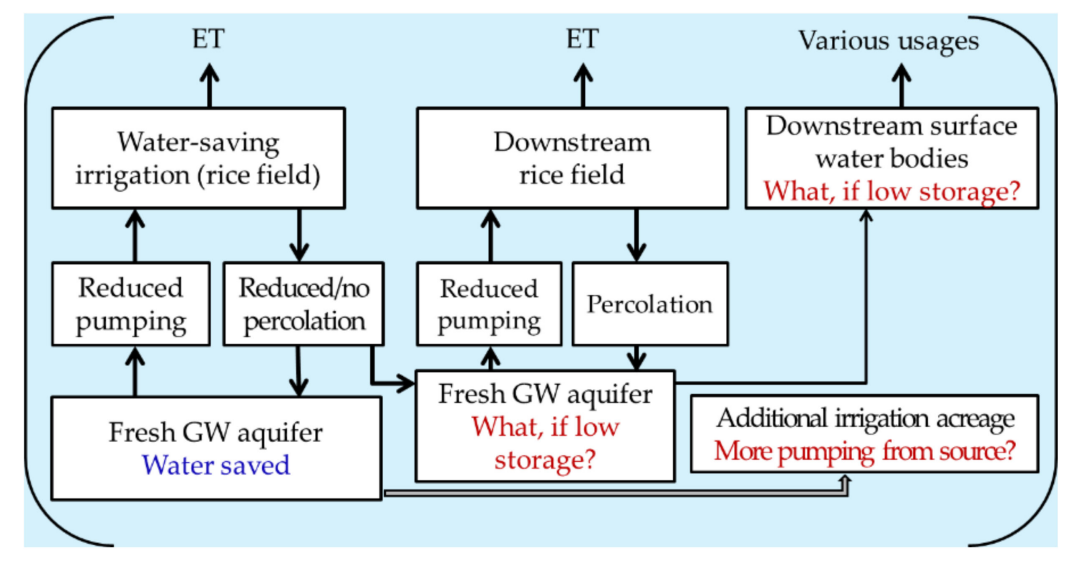

Figure 4. Conceptualizing of impacts of water-saving measures on regional surface and groundwater sources when irrigation uses groundwater. 


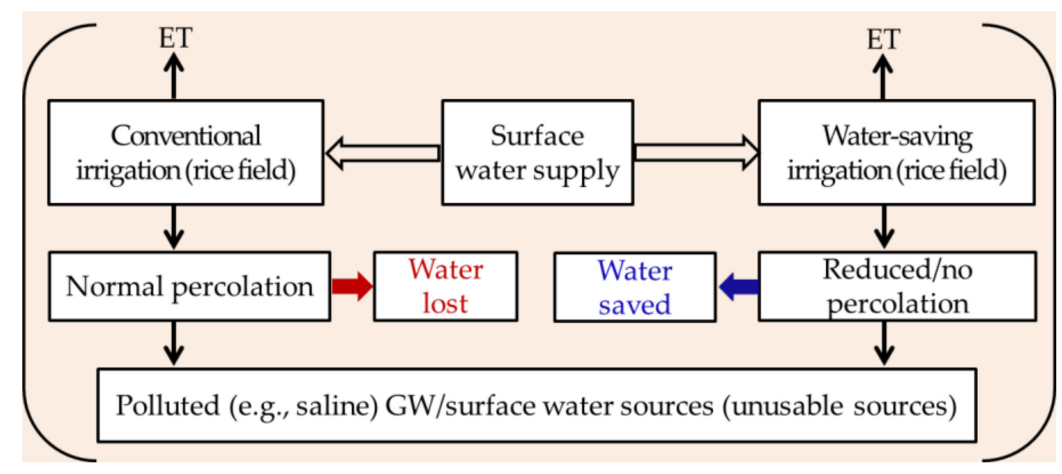

Figure 5. Water loss and water saving issues under conventional and water-saving irrigation from surface water sources when underground aquifer contains polluted water (e.g., saline).

Due to various natural calamities (e.g., seasonal storms, hailstorms, cyclonic storms, heavy rainfall and floods), dry season is the main and safe cropping season in the EGP, which has an annually renewable groundwater system. Here irrigation is predominantly done with groundwater; $79 \%$ of total irrigation in Bangladesh and more than $90 \%$ of irrigation in North-West India uses groundwater. An individual farmer considers the combined outflow of water by evapotranspiration, seepage and percolation as water usage by his/her rice field and hence actual water loss in the field. However, when considering a large spatial scale, achieving water-saving by one user may be a loss to another since the seepage and percolation from one's field enter the underlying aquifer or nearby surface water sources, from where others can reuse the water $[75,103]$ causing no net loss to the system $[205,206]$. The real water-saving occurs only when the non-recoverable non-usable water losses (Figure 2) are eliminated or reduced. Avoidance of peak evaporative demand, use of short-duration varieties, cultivating less water-demanding crops, and changing from ponded to non-ponded rice culture are the potential technologies for reducing evapotranspiration [205-207]. The practicability and effects of technologies on crop yields must, however, be investigated before their large-scale field adoption.

Modifications of the water balance components by resource-conservation technologies, the fate of water saved through reduced application, and hydrologic interactions across spatial scales determine whether any reduction in water application leads to actual watersaving and reduces water usage [75]. Farmers always intend to achieve maximum output from the water resource, leading them to utilize as much water as they can have access to. Society, on the other hand, prefers utilizing scarce water to maximize profits by shifting water from agriculture to high-value economic sectors. The goals of the two entities in utilizing the scarce water are clearly opposing, and therefore appropriate terminology to describe real water-saving remains a central issue of debate [95].

Interactions between non-agricultural and agricultural water usages are scale-depen dent and play a major role in water-saving [208]. At basin scale, the main interest is to reduce water usage in irrigated agriculture and transfer water to other higher-valued usages. This again implies that actual water-saving can be achieved only by reducing evaporation and water-flows to non-recoverable sinks [107]. The basin approach, instead of paying attention to individual water usage, assesses return flows, estimates wateruse efficiencies at field- and basin-scales and differentiates consumptive water-saving from non-consumptive saving (Figure 2) while accounting for water and analyzing wateruse efficiencies [209-213]. Despite many complexities in perceptions of water-saving, its ultimate objectives are clear and undisputable: to stop unsustainable exploitation of the available water resources and to increase the quantity of water for other essential and more beneficial usages. It is therefore essential to understand the scale-effects of water usage clearly to improve water-savings and water productivity [124,210,214-216]. 


\subsection{Impacts on Water Use}

AWD effect: Irrigation management through alternate wetting and drying is widely practiced in many countries/regions like the Philippines, Vietnam, China and EGP [217-220]. Under AWD, the percolation rate decreases leading to water-saving; the reduction in evapotranspiration plays only a minimal role [221]. Compared to the continuous standing water rice system, the levels of water-saving by the AWD method are listed in Table 3. Percolation from the crop fields controls the transport of nitrate [94], heavy metals [222], salts [223], nutrients [224], and pesticides [225] to groundwater. So, with reduced percolation the quality of groundwater remains under safeguard. The AWD method also reduces greenhouse gas emission [226,227], uptake of arsenic in rice grain [228,229], the cost of pumping water $[230,231]$, and concentration of methyl mercury in field soil [232].

Table 3. Levels of water-saving by alternate wetting and drying (AWD) method compared to the continuous standing water rice system.

\begin{tabular}{lcc}
\hline \multicolumn{1}{c}{ Type of Effect } & Quantity & References \\
\hline Water saving & $23 \%$ & {$[108]$} \\
Water saving & $15-40 \%$ & {$[109-111,221,233]$} \\
Water saving & $30-60 \%$ & {$[112]$} \\
Percolation reduction & $50-80 \%$ & {$[112]$} \\
Percolation reduction & $19-28 \%$ & {$[60]$} \\
\hline
\end{tabular}

Bund effect: An unsaturated zone beneath standing water and a higher hydraulic conductivity zone beneath the bunds in rice fields are developed. This causes the applied irrigation water to move through the bunds and recharges the underlying aquifer [234]. The destinations of the applied irrigation in the rice fields were measured on several occasions e.g., $[205,235-238]$ and a significant portion was reported to percolate through the field boundaries. This type of lateral seepage flow field is horizontal first and then vertical below the bunds [239]. Often rice fields of irregular shape are transformed into regular rice fields in order to improve irrigation efficiency, keeping part of the previously generated plow pan beneath the bunds of the reformed rice field [234]. Consequently, the dominant movement of water is in the horizontal direction through the bund. The seepage flux is, however, much less than the deep percolation rate [239-241] except when rice is cultivated on terraced fields, where the seepage water moves to the downstream plots through the bunds [239]. In flat rice fields, the infiltration rate below the bunds remains close to the average infiltration rate for the crop field with plow pan beneath the bunds, but may double or more without plow pan beneath the bunds $[205,239]$. [234] demonstrated $50 \%$ of water lost through the bunds, $25 \%$ through evapotranspiration, and $25 \%$ equally through infiltration providing an estimated annual water loss of $41 \mathrm{~km}^{3}$ through percolation underneath the bunds of rice fields in Bangladesh. Based on this field scale estimate, sealing of bunds (e.g., by puddling) can reduce seasonal water use by $52 \pm 17 \%$. Much greater savings $(\sim 90 \%)$ can be achieved in fields with larger perimeter-to-area ratio.

Puddling effect: Puddling eliminates large pores and alters the field soils to stratified layers: a top puddled layer, muddy layer and plow pan overlying a lower layer [242,243]. A low-permeable layer, formed above the puddled layer, comprises a finer fraction of the soils in suspension [244,245]. Puddling creates a 5 to 10-cm layer of plow pan, of low hydraulic conductivity, $20-25 \mathrm{~cm}$ below the ground surface. The hydraulic properties of plow pan regulate the water regime in the irrigated field [236-247]. Water flow occurs under unsaturated conditions below the plow pan [243]. The percolation rate varies widely with soil texture, 3-17 mm/day for clay and 13-30 mm/day for sandy loam [245,248]. The intensity [249] and depth of puddling [250], soil-type and post-puddling time period [251], and ponding water depth [252] regulate reduction of the percolation rate in the puddled soils. The percolation rate is high during the early growth period but decreases by $35-45 \%$ with the advance of the growth stage [253-255]. 
Re-bound effect: The re-bound effect, a less-known proposition, suggests that when efficiency of using a resource increases, its consumption rate also increases simultaneously [113]. Jevon's contradiction/paradox in economics advocates that any technologies aimed at saving energy actually end up by achieving the contrary of what they were supposed to do. Although the re-bound effect is quite well-known in energy usage [256], it is less known in the irrigation literature. Any intervention to modernize irrigation systems will improve efficiency, reliability and flexibility of the system, with a consequent increase in demand and consumption of water, especially by progressive farmers. The re-bound effect is therefore a potential problem in water resource management as recognized by [117].

Water-saving technologies are promoted based on the supposition that a reduction in water inputs per unit of output makes a comparable water-saving. However, this assumption may not be factual for two reasons. First, whether the quantity of water spared by reducing input transforms into real water-saving depends on the destination of the saved water. A significant part of the applied irrigation water percolates to the underlying aquifer, which can be pumped by the same or other farmers for reuse (Figure 1) and hence is not lost or wasted [212]. So, there is a risk of focusing on local efficiency alone and ignoring the return flows [126]. Secondly, based on economic theory [257], water-saving technologies, by adding more value to water, may encourage farmers to use more water as observed by [114] in Pakistan and Yemen where the overall water usage increased significantly $[127,258]$. Contrasting evidence is also found in the central United States where new technologies reduced water usage [74].

It is crucial to quantify water extracted and water consumed separately in order to effectively investigate the re-bound effect in irrigation. The usage of extracted water can comprise a consumed part and a non-consumed part. The consumed part may comprise both beneficial and non-beneficial evapotranspiration and runoff or percolation loss that are not recoverable. The non-consumed part comprises parts of the runoff and percolation that are recoverable for further use $[213,259]$. So, efficiency improvements do not always reduce overall water use; these actually reduce the effective cost of net irrigation encouraging the farmers to achieve more benefit by increasing net irrigation [115,260-262].

\section{Regional Hydrology Outcomes}

Irrigation water is an important but as yet less characterized component of the hydrological cycle in regions with intensive agricultural irrigation, due to complexity in monitoring [263]. Appropriate differentiation of the natural inter-connection between the surface and groundwater resources is an impending problem [121]. In a highly connected hydrologic system (e.g., EGP), separate management of surface and groundwater will cause conflict in water resource allocation between various sectors (e.g., irrigation, households, industry and fisheries) and exert stress on groundwater-dependent ecosystems [121-123]. Groundwater is mostly a renewable resource in the IGP because of its recharge and depletion mechanisms associated with the regional hydrologic cycle. Water extracted from the aquifers can follow a number of pathways in the hydrologic cycle (Figures 3 and 4), with some travel only over a short distance, and may not join the aquifer [264,265]. Recharge to the aquifers occurs through rainfall, seepage and percolation from rivers and canals, and irrigation return flow [99], with rainfall and irrigation return flow remaining as the major contributors for many groundwater basins $([97,98,102])$. So irrigation return flow that depends on soil hydraulic properties and irrigation management practices [266] is an important outcome of irrigated rice fields [96,100,267].

Abstraction of groundwater lowers the water table in aquifers with resulting reduction in groundwater pressure head that induces groundwater recharge by drawing down water from surface sources into aquifers [268,269]. Most rivers in the Bengal Basin, having direct hydraulic contact with aquifer systems $[119,120]$ recharge the aquifers during March to November and receive water from the aquifers during December to February. These water exchange behaviors imply that groundwater tables can be deliberately lowered to more extent in the dry season to accommodate more recharge during the monsoon. This 
intervention, first put forward in the 1970s [270] and then re-examined occasionally [271], will increase groundwater reserve for irrigation during the dry season and also help control flooding during the monsoon.

Percolation from irrigated rice fields is important to the economy, environment and water resource conservation in irrigated rice-dominated South Asian countries like Bangladesh, India and Taiwan. Flooded rice fields are comparable to wetlands [101,272] and play an important role in raising groundwater level [273]. The recharge potential of rice fields is $69.2 \mathrm{~cm}$ for sandy loam and $37.2 \mathrm{~cm}$ for clay loam in India [274], between 1-2 $\mathrm{mm} /$ day and $7.5 \mathrm{~mm} /$ day in Bangladesh [275], and 21.2-23.4\% of the applied irrigation water from the terraced rice fields in northern Taiwan [239]. The groundwater-dominated irrigation in Bangladesh has changed the nature of aquifer recharge and the flow patterns of groundwater with a resulting reduction in residence time of water in the aquifer, especially in the shallow aquifers [276]. Recharge from the irrigation fields can be significantly modified by changes in irrigation management practices [77,118].

Adoption of agricultural water-saving technologies at the farm level changes cropwater use and regional hydrology [38] by reducing groundwater recharge. In many groundwater irrigated areas of the EGP (e.g., the North-West region of Bangladesh) the aquifers are not currently recharged fully from other sources (e.g., rainfall and interflow from adjacent aquifers). Consequently, water-saving technologies cause decreased opportunities for groundwater irrigation. There are other factors (e.g., canal lining, reduced water diversion, leveling undulating lands) that also reduce recharge by restricting percolation with eventual decline of groundwater tables. Some countries (e.g., China) widely use mulched-drip irrigation system, which significantly modifies the dynamics of regional groundwater by changing water exchange flux between the irrigation fields and underlying aquifer [39]. The exchange flux at the groundwater table during drip irrigation period is downward and remarkably reduces after adoption of water-saving technologies [39]. Adoption of efficient water-saving measures at regional scales would significantly restrict groundwater recharge with a consequent decline in groundwater levels [40]. This will exert negative impacts on regional hydrology and ecology by degrading soil quality and deforesting, particularly in arid regions [43]. With decades of large-scale groundwater withdrawal and reduced recharge opportunity due to increasing urbanization and decreasing wetlands, water tables have already declined significantly and are continuously declining in many large urban areas (e.g., Dhaka city in Bangladesh) over time [3]. There is, however, evidence of induced groundwater recharge due to the creation of significant vertical head gradients by increasing pumping in areas with shallow water tables and permeable upper soil formation [277]. This implies that dry season abstraction of groundwater can create storage space in the aquifer that can be utilized for harvest in the monsoon. Such intervention would exert a positive contribution on overall water availability in the area [131]. The main threat in the IGP Basin is not considered to be the diminished quantity of groundwater, but the degraded water quality resulting from high arsenic and salt contents [54].

\section{Gaps in Current Knowledge}

\subsection{Uncertainty in Water-Saving}

The reported impacts of conservation agriculture on water-saving are yet to be ascertained and evaluated more rigorously [278-282]. Water moves through very complex pathways and the impacts of conservation agriculture are so far understandable only at field-scale, but not at the larger scale [75]. Puddling forms plow pan and also creates soil cracks in addition to preferential flow paths. Consequently, increasing percolation, instead of commonly reported decreasing percolation, has been also reported [283]. In groundwater-based irrigation systems, improved irrigation efficiency and consequent water-saving achieved by reducing irrigation applications with water-saving technologies are clearly understood at the field-scale $[115,116]$. However, due to the lack of measurement of the water balance components, these are poorly understood at a larger spatial scale $[75,106,116,125]$. When farmers in a region reduce percolation substantially, which 
would ultimately recharge a usable aquifer or join to a usable surface water body on the one hand but may also increase the irrigated area with the saved water on the other (Figure 4), the overall impact may be unintended. Instead of saving water, it can actually increase water consumption and reduce water availability for other users $[95,116]$.

The growth period of rice with high evaporative demand can be avoided by shifting planting time. Adoption of short-duration varieties will also reduce evapotranspiration and percolation loss of water. The effects of these alternative crop technologies on water losses and crop yield have not been investigated adequately yet. If field-level estimates of water-saving are extrapolated to larger spatial scales in rice-based cropping systems that utilize recycled water or surface and groundwater conjunctively, there is a possibility of underestimating the real water-saving [284]. The concept of classical irrigation efficiency for an entire basin becomes erroneous and misleading when irrigation management is considered for the water resources of a region as a whole. The discrepancy arises since the water losses with respect to which the classical irrigation efficiency is calculated are not the actual water losses when considering the whole system. It is not possible to clearly know the extent of water-savings until the destination of the lost water is correctly known [95]. It is not yet clear how the water-saving technologies alter the dynamics of overall water balance. Whether application of water-saving technologies can maintain sustainable development and what else needs to be done for this in future are still major questions [39].

\subsection{Limited Knowledge of Recharge-Discharge Interaction}

Groundwater recharge occurs from several sources (e.g., rainfall, flood water, irrigation return flow, inter-basin transfer, etc.) through several processes, the complexity of which varies widely. In an inefficient surface water irrigation system, a large fraction of the applied irrigation water percolates to the underlying aquifer, causing a significant loss of water when considering irrigation efficiency. However, this irrigation system appears as one of the most efficient methods of recharging groundwater, as occurs in most parts of Bangladesh, India, Pakistan and elsewhere [54,99]. So, the common perception of more efficient irrigation systems that can reduce seepage and percolation losses must be thought about with great caution.

A reliable quantification of groundwater recharge from irrigation fields, although essential in order to know its impending impacts on the dynamics and quality of groundwater, is difficult and remains unresolved in regions with confined aquifers. The groundwater table is confounded with both recharge from irrigation fields and extraction by irrigation wells. Many factors like soil type and surface condition, vegetation, depth to groundwater level, and chemical quality of soil and irrigation water control groundwater recharge. Although groundwater flow and recharge from rice fields have been examined on many occasions e.g., $[101,246,285-287]$, the effects of land use conditions on recharge and groundwater level are not yet clear [288]. When groundwater is abstracted from an aquifer, recharge from surface sources occurs under transient conditions. The knowledge of soilwater flux in the vadoze zone that can help understanding the transient recharge [289] is still limited [290]. Therefore, a major pre-requisite for sustainable groundwater management is to reduce the uncertainty in aquifer recharge from rice fields.

\subsection{Uncertain Causes of Groundwater Decline}

Large-scale withdrawal of groundwater, increased Boro rice cultivation, dry season reduction in river flow, reduction in wetland areas, declining annual rainfall, low recharge potentiality of soils, and lack of recharging of aquifers through artificial methods are regarded as the major barriers to sustainable groundwater use in the IGP basin [291]. These factors, in their various combinations, are causing decline in groundwater level in some regions in the EGP (e.g., North-West region of Bangladesh; [49]). In a groundwater irrigation system, reduced application of irrigation may be an effective way to check groundwater level depletion [292], although contrasting results were also reported [293-295]. These 
contrasting opinions and observations raise valid questions of how far irrigation return flow contributes to groundwater recharge.

Field-level water-savings can make water use more profitable by increasing crop-water productivity and may lead to greater total water use in the basin $[75,116]$. Mere adoption of resource-conservation technologies cannot guarantee overall water-saving unless the usage of saved water can be controlled by proper policies and regulations. However, regionalscale study is still scarce for the evaluation of impacts of water-saving on evaporation and groundwater levels [296]. A proper policy to achieve stabilized groundwater levels must not consider only the adoption of technology and management of users' demand; recharging the aquifer artificially and finding alternative water sources, i.e., supply side management, is also necessary in some situations [64]. To establish sustainable levels of groundwater usage and achieve maximum benefit therefrom, investigation of the feasibility of combination of demand management, recharge improvement and alternative water supplies are crucial [297].

\subsection{Inadequate Understanding of Scale-Effects}

Improved irrigation methods and conveyance systems are essential to increase efficiency of water use. However, water loss through deep percolation has the possibility of reuse in another region and the quality of percolated water may undergo changes during transmission through the hydrological units. It is therefore essential to account for the usages of surface water and groundwater, losses of water while being used, and interactions of various water components at the field scale and basin scale by adopting a system approach [67]. The common system approach of water accounting requires that, in closed basins, all lost water is presumed to be re-used somewhere downstream and hence any intervention to increase efficiency of water use would not make significant water-savings. So, there is hardly any scope for water-scarce regions to reduce water stress, especially through improvement in efficiency of water use. This approach has three major faults [298]. This disregards a major element of unproductive water use, values only new water without sufficiently considering water productivity in a broader aspect, and fails to account for several co-benefits arising from increasing efficiency of water use (e.g., upgraded water quality, increased reliability and less energy demand). Because of the complexity of the impacts of water-saving technologies at large scales, good approaches must integrate the conceivable spatial and temporal effects. Often a three-dimensional surface-groundwater interaction approach [299] is considered for this; but the problem remains as yet unexplored.

\subsection{Weakness in Policy}

In the past, agricultural water management generally concentrated attention on irrigation options and water withdrawals from rivers and aquifers. Now it dedicates more attention to managing rainwater, evapotranspiration and water reuse, and views land-use decisions as water-use decisions [103]. In current perceptions of water management, considerable water-savings can be realized if the water-saving options are assessed in terms of technical, economic and institutional aspects and selections are made based on their efficacy [67]. Although technologies play a vital role in reducing water applications per unit of crop production, the re-bound effect is always a problem. If the increase in cultivated area of a certain crop, or even the irrigated area due to the re-bound effect, can be adequately known, the regional impacts of water-saving measures could also be scientifically explainable. However, restricting the demand of water is a challenging issue $[75,127]$ with weak institutional arrangements. In the IGP, instability in the market price of agricultural products often guides the farmers to choose crops irrespective of the set policy. The performances of water-saving technologies contrast, and their adoption is a widely debated issue. Nonetheless, promoting water-saving technologies is a popular policy for governing groundwater in many countries (e.g., Bangladesh, India, China, Spain, Mexico, and the USA). Lack of attention, proper legislation, and ineffective or less-effective institutions are the main difficulties in governing groundwater in many least-developed and developing 
countries [128]. In cases when aquifers extend across more than one independent country, groundwater governance becomes extremely complex [131].

When the groundwater table is very close to the surface (within capillary rise) the declining groundwater table can increase percolation rates by increasing the hydraulic gradient that would not have happened with a deeper groundwater table. It is speculated that this will offset the gains, at least to some extent, that the adopted water-saving technologies can offer. The recharge of shallow aquifers is therefore an important mechanism that needs to be well-understood for effective management of aquifers [300]. As the scale of water use extends, water loss increases, with resulting decrease in traditional irrigation efficiency. In contrast, water recycling increases with extending scale of water use, with eventual increase in net efficiency except when recycling is not feasible at the system level. This scenario of water usage suggests that the term 'irrigation efficiency' can lead policy planners to miscommunication and misunderstanding. While the problems of groundwater are clearly intuitive, the solutions are not. Enactment of wrong, flawed or misemployed concepts of efficiency in water-resource strategy and management can bring about many unexpected problems [78]. An example is the assumption that the rate of natural groundwater recharge is the safe yield of an aquifer [301]. This water budget myth ignores the factual possibility of increasing recharge and/or decreasing discharge from the aquifer due to groundwater extraction [199]. Our knowledge of the nature of interconnection between surface and groundwater systems over a large spatial scale is not yet adequate. Consequently, many water managers have been suffering in formulating strategy and establishments separately, rather than based on the linked inter-connection of surface water and groundwater. It is important that groundwater systems are treated as complex systems, which respond dynamically to abstraction-induced perturbation. A correct account of the vadoze zone in irrigation fields [302] can enable assessment of the impacts of change and of interventions to be prioritized [77].

Effective governance, although lacking in many countries, is a prerequisite for sound water resource management [129]. Because of existing political structures and systems, adopting a policy of restricting tube wells to reduce groundwater extraction in the IGP basin seems unrealistic. Several states in India have adopted regulations to prevent/minimize groundwater mining but could not implement these regulations totally [303,304]. In Bangladesh, reliable and detailed information on water reserves, safe yield, water withdrawal patterns and groundwater quality dynamics of aquifers is lacking [130]. These knowledge gaps have raised serious concerns about sustainable use of groundwater for irrigation, especially in the North-West region of the country [305]. Recently, emphasis has been placed on increasing dry season Boro rice production in the southern zone to reduce stress on groundwater use in the North-West region [306]. However, the viability of this approach remains to be cross-examined. The potential major restrictive factors are salinity problems of soil and water, weakness in synchronized water governance and the likely effects of climate change in the southern region [130,307,308]. In Bangladesh, there are specific problems in governing groundwater usage. The number of groundwater users is very large, most water users are resource-poor, and the institutional settings are mostly ineffective to ensure execution of laws and regulations. Under such a situation, enforcement of water rights and controlling access to groundwater by permit systems are probably not feasible options. A well-conceived rational and persistent strategy is appropriate for groundwater governance. Some prospective drivers of success may be engagement of users, refinements in water pricing structures, inspiring farmers to move from high to less water-demanding crops [53], in situ rainwater conservation, deficit irrigation, modifying rice-wheat areas [309], extensive investments in technology, and advancement of proactive policies and decision-making systems. Certainly, all these options will not be equally effective at all times and places since groundwater dynamics are localized; local countermeasures, such as managed aquifer recharge, can be implemented [9]. The best option(s) for governing groundwater at specific times and locations must be, however, identified through policy research [130]. 
Artificial recharge to aquifers through natural drains, canals and topographical depressions is a technically feasible and economically viable option [310] in the EGP. However, this option needs to be within a proper policy framework for its implementation. If groundwater-irrigated areas are not further increased, groundwater levels are expected either not to decline further or decline at much smaller rates than currently. With checked groundwater-irrigated areas, the other possibility is that groundwater levels will attain a new equilibrium that will be lower than at the current level. This proposition, yet to be considered in national policy, implies that the existing abstraction rates of groundwater can be continued and the presumed lower groundwater levels will not hamper the environment and economic and social developments [311]. However, these suggested potentials are only propositions and because of widely variable hydro-climatic, political and socioeconomic conditions among the affected regions no single solution will be adequate for groundwater management. The most logical strategy would be to select, from among the available options, regionally-suited strategies and establish strong regulation and policy for management of regional water resources [131-133]. Therefore, sustainable long-term strategies that are appropriate and adaptable for individual regions need to be recognized and exchange of knowledge and actions between regions must be established. Thus, establishing region-specific strategy and communication systems [134] will be important topics for future research in the IGP basin.

\section{Summary and Conclusions}

Manifold attempts have been made in different regions of the world to increase food production for the rapidly growing population since the early 1960s. There has been great success in increasing food production globally but with a tremendous resulting pressure on the production-linked resources, specifically water and soil. The accelerating stress on these vital resources in the EGP raises sustainability concerns regarding agricultural production systems. Researchers and practitioners have been facing these challenges, both locally and regionally, over the last few decades. They have developed resourceconservation technologies as a response to concerns about agricultural sustainability, with basic principles of rebuilding the soil, optimizing inputs for crop production, increasing food production, and optimizing profits $[84,86,87]$. This review study has summarized the benefits of these technologies, and the scale-dependency and uncertainty of some of the benefits. Also identified are the gaps in current knowledge regarding the conceptual aspects of these technologies to make agriculture sustainable over a large regional scale so as to guide the future research in proper directions.

Of these resource-conservation technologies, conservation agriculture and water-saving measures are being practiced in many regions of the world, including the EGP [85,87]. Some benefits of these technologies, such as reduced energy and nutrients usage and reduced agrochemical leaching, are scale-invariant and intuitively clear $[37,83]$. However, the issue of water-saving remains uncertain at the system level since it is both a temporal and spatial scale-dependent element and linked to the regional hydrologic cycle [94,95]. Water saved at the farm level could otherwise join the groundwater or surface water systems to be used later by the same or other users $[75,103]$. Consequently, whether water-saving achieved at the farm level makes any real saving when considering the entire groundwater or river basin has not yet been adequately investigated. Furthermore, there is evidence of increasing demand for water after adding more value by technological interventions, such as increasing irrigation efficiency by adopting water-saving measures [114]; however, contrasting evidence has also been observed [74]. Whether or not the reduced extraction of groundwater, as well as reduced recharge, under resource-conservation technologies raise groundwater storage/groundwater level or reduce it remains unresolved [306]. Apparently, the reduced extraction of groundwater is expected to increase groundwater storage, but this likelihood is also uncertain since most aquifers in the Gangetic basin discharge to the rivers as base flow in the dry season. Thus, the current level of understanding of the complexity of the hydrological link to field-applied water is inadequate due to lack of 
measured data on the components of regional water balance. Lack of shared knowledge on the impacts of resource-conservation technologies on regional water balance among the pertinent disciplines, such as agricultural production practitioners (e.g., agronomists, economists, irrigation engineers) and hydrologists (e.g., groundwater hydrologists, surface water hydrologists), is another drawback in planning and implementing holistic approach to investigate regional hydrology outcomes. This inadequate knowledge of inter-linked water systems may lead to the implementation of wrong policy [121-123] merely based on local perspectives with eventual worsening of the water-scarcity situation. Therefore, all pertinent disciplines should adopt integrated research approaches to measure the components of local and regional water balance and quantify regional hydrology outcomes over a large temporal scale. Only then proper water management policy can be planned and implemented for sustainable agricultural production.

Author Contributions: Conceptualization, M.A.M.; funding acquisition, M.M.; writing-original draft, M.A.M.; writing-review and editing, M.A.M. Both authors have read and agreed to the published version of the manuscript.

Funding: The study was funded by the Australian Centre for International Agricultural Research (ACIAR) under the project 'The regional hydrological impact of farm-scale water saving measures in the eastern Gangetic plains'.

Institutional Review Board Statement: Not applicable.

Informed Consent Statement: Not applicable.

Data Availability Statement: The data presented in this study are available on request from the corresponding author.

Acknowledgments: The authors gratefully acknowledge the contributions of the authorities of Bangladesh Agricultural University (BAU) in Bangladesh and Commonwealth Scientific and Industrial Research Organization (CSIRO) in Australia in conducting this study. The BAU authority granted a 2-week leave to the principal author to visit CSIRO, which provided access to their electronic academic resources to facilitate conducting this study.

Conflicts of Interest: The authors declare to have no conflicts of interest.

\section{References}

1. Parry, M. Food and energy security: Exploring the challenges of attaining secure and sustainable supplies of food and energy. Food Energy Secur. 2012, 1, 1-2. [CrossRef]

2. World Bank. World Development Report: Agriculture for Development; World Bank: Washington, DC, USA, 2008.

3. Fendorf, S.; Benner, S.G. Hydrology: Indo-Gangetic groundwater threat. Nat. Geosci. 2016, 9, 732-733. [CrossRef]

4. Bharati, L.; Sharma, B.R.; Smakthin, V. (Eds.) The Ganges River Basin: Status and Challenges in Water, Environment and Livelihoods, 1st ed.; Routledge: London, UK/New York, NY, USA, 2016.

5. Jain, M.; Singh, B.; Srivastava, A.A.K.; Malik, R.K.; McDonald, A.J.; Lobell, D.B. Using satellite data to identify the causes of and potential solutions for yield gaps in India's Wheat Belt. Env. Res. Lett. 2017, 12, 094011. [CrossRef]

6. Soneja, S.I.; Tielsch, J.M.; Khatry, S.K.; Curriero, F.C.; Breysse, P.N. Highlighting uncertainty and recommendations for improvement of black carbon biomass fuel-based emission inventories in the Indo-Gangetic Plain region. Curr. Environ. Health Rep. 2016, 3, 73-80. [CrossRef]

7. Bhanja, S.N.; Mukherjee, A.; Rangarajan, R.; Scanlon, B.R.; Malakar, P.; Verma, S. Long-term groundwater recharge rates across India by in situ measurements. Hydrol. Earth Syst. Sci. 2019, 23, 711-722. [CrossRef]

8. Timsina, J.; Connor, D.J. Productivity and management of R-W cropping systems: Issues and challenges. Field Crops Res. 2001, 69, 93-132. [CrossRef]

9. Urfels, A.; McDonald, A.J.; Krupnik, T.J.; van Oel, P.R. Drivers of groundwater utilization in water-limited rice production systems in Nepal. Water Int. 2020, 45, 39-59. [CrossRef]

10. Narayanamoorthy, A.; Deshpande, R.S. Where Water Seeps: Towards a New Phase in India's Irrigation Reforms; Academic Foundation: New Delhi, India, 2005.

11. Narayanamoorthy, A.; Hanjra, M.A. Rural infrastructure and agricultural output linkages: A study of 256 Indian districts. Indian J. Agric. Econ. 2006, 61, 444-459.

12. Vaidyanathan, A.; Krishanakumar, A.; Rajagopal, A.; Varatharajan, D. Impact of irrigation on productivity of land. J. Indian School Polit. Econ. 1994, 6, 60-145. 
13. Renner, J. Global Irrigated Area at Record Levels, But Expansion Slowing; Worldwatch Institute: Washington, DC, USA, 2012. Available online: http:/ / www.worldwatch.org/global-irrigated-area-record-levels-expansion-slowing (accessed on 4 September 2019).

14. BADC (Bangladesh Agricultural Corporation). Data on Irrigation and Groundwater Tables; Bangladesh Agricultural Development Corporation: Dhaka, Bangladesh, 2016.

15. Zilberman, D.; Taylor, R.; Shim, M.E.; Gordon, B. How politics and economics affect irrigation and conservation. Choices 2017, 32 $1-6$.

16. Santeramo, F.G. On the composite indicators for food security: Decisions matter. Food Rev. Int. 2015, 31, 63-73. [CrossRef]

17. Loeve, R.; Dong, B.; Hong, L.; Chen, C.D.; Zhang, S.; Barker, R. Transferring water from irrigation to higher valued uses: A case study of the Zhanghe irrigation system in China. Paddy Water Environ. 2007, 5, 263-269. [CrossRef]

18. Godfray, H.C.J.; Beddington, J.R.; Crute, I.R.; Haddad, L.; Lawrence, D.; Muir, J.F.; Pretty, J.; Robinson, S.; Thomas, S.M.; Toulmin, C. Food security: The challenge of feeding 9 billion people. Science 2010, 327, 812-818. [CrossRef] [PubMed]

19. Leemans, R.; de Groot, R.S. Millennium Ecosystem Assessment: Ecosystems and Human Well-Being; Island Press: Washington, DC, USA, 2005; Volume 5.

20. Hoque, M.A.; Burgess, W.G. 14C-dating of deep groundwater in the Bengal Aquifer System, Bangladesh: Implications for aquifer anisotropy recharge sources and sustainability. J. Hydrol. 2012, 444, 209-220. [CrossRef]

21. Federico, G. Feeding the World: An Economic History of Agriculture, 1800-2000, 1st ed.; Princeton University Press: New York, NY, USA, 2008

22. Hansen, J.; Hellin, J.; Rosenstock, T.; Fisher, E.; Cairns, J.; Stirling, C.; Lamanna, C.; van Etten, J.; Rose, A.; Campbell, B. Climate risk management and rural poverty reduction. Agric. Syst. 2019, 172, 28-46. [CrossRef]

23. Shah, T.; Roy, A.D.; Qureshi, A.S.; Wang, J. Sustaining Asia's Groundwater Boom: An Overview of Issues and Evidence. In Natural Resources Forum; Blackwell Publishing Ltd.: Oxford, UK, 2003; Volume 27, pp. 130-141. [CrossRef]

24. FAO (Food and Agriculture Organization of the United Nations). AQUASTAT: FAO Database. Available online: http://www.fao. $\mathrm{org} / \mathrm{nr} /$ water/aquastat/data/query/index.html (accessed on 12 September 2020).

25. Cassman, K.G. Ecological intensification of cereal production systems: Yield potential, soil quality and precision agriculture. Proc. Natl. Acad. Sci. USA 1999, 96, 5952-5959. [CrossRef]

26. Alam, K. Farmers' adaptation to water scarcity in drought-prone environments: A case study of Rajshahi District, Bangladesh. Agric. Water Manag. 2015, 148, 196-206. [CrossRef]

27. Ladha, J.K.; Pathak, H.; Gupta, R.K. Sustainability of the rice-wheat crop-ping system: Issues, constraints, and remedial options. J. Crop Improv. 2007, 19, 125-136. [CrossRef]

28. Hira, G.S. Water management in northern states and the food security of India. J. Crop Improv. 2009, 23, 136-157. [CrossRef]

29. Humphreys, E.; Kukal, S.S.; Christen, E.W.; Hira, G.S.; Sharma, R.K. Halting the Groundwater Decline in North-West IndiaWhich Crop Technologies Will Be Winners? Adv. Agron. 2010, 109, 155-217.

30. Stevenson, J.R.; Villoria, N.; Byerlee, D.; Kelley, T.; Maredia, M. Green Revolution research saved an estimated 18 to 27 million hectares from being brought into agricultural production. Proc. Natl. Acad. Sci. USA 2013, 110, 8363-8368. [CrossRef]

31. Montpellier Panel. Sustainable Intensification: A New Paradigm for African Agriculture, London. 2013. Available online: https: / / farmingfirst.org/2013/04/sustainable-intensification-a-new-paradigm-for-african-agriculture/ (accessed on 26 February 2021).

32. Kabir, M.S.; Salam, M.U.; Chowdhury, A.; Rahman, N.M.F.; Iftekharuddaula, K.M.; Rahman, M.S.; Rashid, M.H.; Dipti, S.S.; Islam, A.; Latif, M.A.; et al. Rice vision for Bangladesh: 2050 and beyond. Bangladesh Rice J. 2015, 19, 1-18. [CrossRef]

33. Bhanja, S.N.; Mukherjee, A.; Rodell, M.; Wada, Y.; Chattopadhyay, S.; Velicogna, I.; Pangaluru, K.; Famiglietti, J.S. Groundwater rejuvenation in parts of India influenced by water-policy change implementation. Sci. Rep. 2017, 7, 7453. [CrossRef]

34. Gleick, P.H.; Heberger, M. Water and Conflict. In The World's Water; Island Press: Washington, DC, USA, 2014 ; pp. 159-171.

35. PARC-RWC. Pakistan Agricultural Research Council-Rice-Wheat Consortium (PARC-RWC) for the Indo-Gangetic Plains. In Proceedings of the National Workshop on Rice-Wheat Systems, Islamabad, Pakistan, 11-12 December 2002; Pakistan Agricultural Research Council and Rice-Wheat Consortium for the Indo-Gangetic Plains: Islamabad, Pakistan/New Delhi, India, $2003 ;$ p. 118.

36. Mujeeb-ur-Rehman, H.; Ali, S.; Akram, M.M. Resource conservation strategy for enhancing wheat productivity in Pakistan. Mycopath 2011, 9, 79-85.

37. Tesfaye, K.; Khatri-Chhetri, A.; Aggarwal, P.K.; Mequanint, F.; Shirsath, P.B.; Stirling, C.M.; Jat, M.L.; Rahut, D.B.; Erenstein, O. Assessing climate adaptation options for cereal-based systems in the eastern Indo-Gangetic Plains, South Asia. J. Agric. Sci. 2019, 157, 189-210. [CrossRef]

38. Liu, Z.; Chen, H.; Huo, Z.; Wang, F.; Shock, C.C.; Clothier, B.E. Analysis of the contribution of groundwater to evapotranspiration in an arid irrigation district with shallow water table. Agric. Water Manag. 2016, 171, 131-141. [CrossRef]

39. Zhang, Z.; Hu, H.; Tian, F.; Yao, X.; Sivapalan, M. Groundwater dynamics under water-saving irrigation and implications for sustainable water management in an oasis: Tarim River basin of western China. Hydrol. Earth Syst. Sci. 2014, 18, $3951-3967$. [CrossRef]

40. Tabbal, D.F.; Bouman, B.A.M.; Bhuiyan, S.I.; Sibayan, E.B.; Sattar, M.A. On-farm strategies for reducing water input in irrigated rice; case studies in the Philippines. Agric. Water Manag. 2002, 56, 93-112. [CrossRef]

41. Mays, L.W. Groundwater resources sustainability: Past, present, and future. Water Resour. Manag. 2013, 27, 4409-4424. [CrossRef]

42. Grogan, D.S.; Wisser, D.; Prusevich, A.; Lammers, R.B.; Frolking, S. The use and re-use of unsustainable groundwater for irrigation: A global budget. Environ. Res. Lett. 2017, 12, 034017. [CrossRef] 
43. Chen, H.; Liu, Z.; Huo, Z.; Qu, Z.; Xia, Y.; Fernald, A. Impacts of agricultural water saving practice on regional groundwater and water consumption in an arid region with shallow groundwater. Environ. Earth Sci. 2016, 75, 1204. [CrossRef]

44. Shahid, S. Spatial and temporal characteristics of droughts in the western part of Bangladesh. Hydrol. Process. 2008, 22, 2235-2247. [CrossRef]

45. Shahid, S.; Behrawan, H. Drought risk assessment in the western part of Bangladesh. Nat. Hazards 2008, 46, 391-413. [CrossRef]

46. Jahan, C.; Mazumder, Q.H.; Islam, A.T.M.M.; Adham, M. Impact of irrigation in Barind area, North-west Bangladesh-an evaluation based on the meteorological parameters and fluctuation trend in groundwater table. J. Geol. Soc. India 2010, 76, 134-142. [CrossRef]

47. Jahan, C.; Mazumder, Q.H.; Akter, N.; Adham, M.I.; Zaman, M. Hydrogeological environment and groundwater occurrences in the plio-pleistocene aquifer in Barind area, North-west Bangladesh. Bangladesh Geosci. J. 2012, 16, $23-37$.

48. Shamsudduha, M.; Taylor, R.; Longuevergne, L. Monitoring groundwater storage changes in the highly seasonal humid tropics: Validation of GRACE measurements in the Bengal Basin. Water Resour. Res. 2012, 48, W02508. [CrossRef]

49. Mojid, M.A.; Parvez, M.F.; Mainuddin, M.; Hodgson, G. Water table trend-A sustainability status of groundwater development in North-West Bangladesh. Water 2019, 11, 1182. [CrossRef]

50. Takara, K.; Ikebuchi, S. Japan's 1994 drought in terms of drought duration curve. In Proceedings of the 5th Symposium of Water Resources, Japan, 12-14 November 1997; pp. 467-477.

51. Sajjan, A.; Muhammed, B.; Dey, N.C. Impact of 1994-95 Drought in the North-West of Bangladesh through Questionnaire Survey. In Proceedings of the 2nd Annual Paper Meet of Agriculture Engineering Division; Institution of Engineers: Bangladesh, 2002; Volume 35, pp. 31-35.

52. Dey, N.C.; Alam, M.S.; Sajjan, A.K.; Bhuiyan, M.; Ghose, L.; Ibaraki, Y.; Karim, F. Assessing environmental and health impact of drought in the North-west Bangladesh. J. Environ. Sci. Nat. Resour. 2011, 4, 89-97. [CrossRef]

53. Dey, N.C.; Saha, R.; Parvez, M.; Bala, S.K.; Islam, A.S.; Paul, J.K.; Hossain, M. Sustainability of groundwater use for irrigation of dry-season crops in northwest Bangladesh. Groundwater Sustain. Dev. 2017, 4, 66-77. [CrossRef]

54. MacDonald, A.M.; Bonsor, H.C.; Ahmed, K.M.; Burgess, W.G.; Basharat, M.; Calow, R.C.; Dixit, A.; Foster, S.S.D.; Gopal, K.; Lapworth, D.J.; et al. Groundwater Quality and Depletion in the Indo-Gangetic Basin Mapped From in Situ Observations. Nat. Geosci. 2016, 9, 762-766. [CrossRef]

55. Akhilesh, S. Zero tillage - A profitable resource conservation technology in agriculture. Adv. Plants Agric. Res. 2017, 6, 24-25. [CrossRef]

56. Gatto, M.; Petsakos, A.; Hareau, G. Sustainable Intensification of Rice-Based Systems with Potato in Eastern Indo-Gangetic Plains. Am. J. Potato Res. 2020, 97, 162-174. [CrossRef]

57. ICAR (Indian Council of Agricultural Research). State-Specific Interventions for Higher Agricultural Growth. 2018. Available online: http:/ / www.icar.org.in/files/state-specific/chapter/125.htm (accessed on 11 September 2020).

58. Wolff, P.; Stein, T.M. Water efficiency and conservation in agriculture-opportunities and limitations. Agric. Rural Dev. 1998, 2, $2-20$.

59. Liu, Y.; Yu, X.; He, Y. The Research Progress of Water-Saving Irrigation in China Since 2000. In Advanced Materials Research; Trans Tech Publications Ltd.: Bach, Switzerland, 2014; Volume 955, pp. 3206-3210. [CrossRef]

60. Tan, X.; Shao, D.; Gu, W.; Liu, H. Field analysis of water and nitrogen fate in lowland paddy fields under different water managements using HYDRUS-1D. Agric. Water Manag. 2015, 150, 67-80. [CrossRef]

61. Lamaddalena, N.; Shatanawi, M.; Todorovic, M.; Bogliotti, C.; Albrizio, R. Water use efficiency and water productivity. WASAMED Projects (EU Contract ICA3-CT-2002-10013). In Proceedings of the 4th WASAMED Workshop, Aman-Jordan. Options Mediterraneennes SERIES B: Studies and Research, Bari, Italy, 26-30 September 2005; Number 57, CIHCIHEAM/IAMB-EU DG IAMB. 2007; pp. 5-6.

62. Perry, C.; Steduto, P.; Allen, R.G.; Burt, C.M. Increasing productivity in irrigated agriculture: Agronomic constraints and hydrological realities. Agric. Water Manag. 2009, 96, 1517-1524. [CrossRef]

63. Heydari, N. Water productivity in agriculture: Challenges in concepts, terms and values. Irrig. Drain. 2014, 63, 22-28. [CrossRef]

64. Fishman, R.; Devineni, N.; Raman, S. Can improved agricultural water use efficiency save India's groundwater? Environ. Res. Lett. 2015, 10, 084022. [CrossRef]

65. Wang, M.H.; Shao, G.C.; Meng, J.J.; Chen, C.R.; Huang, D.D. Variable fuzzy assessment of water use efficiency and benefits in irrigation district. Water Sci. Eng. 2015, 8, 205-210. [CrossRef]

66. Gonçalves, J.M.; Pereira, L.S.; Fang, S.X.; Dong, B. Modelling and multi criteria analysis of water saving scenarios for an irrigation district in the upper Yellow River Basin. Agric. Water Manag. 2007, 94, 93-108. [CrossRef]

67. Khan, S. Pathways for Realizing Water Conservancy in Irrigation Systems. In Proceedings of the International Forum on Water Resources Management and Irrigation Modernization in Shanxi Province, China; FAO Rap Publication: Roma, Italy, 2007.

68. Pereira, L.S.; Gonçalves, J.M.; Dong, B.; Mao, Z.; Fang, S.X. Assessing basin irrigation and scheduling strategies for saving irrigation water and controlling salinity in the upper Yellow River Basin, China. Agric. Water Manag. 2007, 93, 109-122. [CrossRef]

69. Han, D.; Song, X.; Currell, M.J.; Cao, G.; Zhang, Y.; Kang, Y. A survey of groundwater levels and hydro-geochemistry in irrigated fields in the Karamay agricultural development area, Northwest China: Implications for soil and groundwater salinity resulting from surface water transfer for irrigation. J. Hydrol. 2011, 405, 217-234. [CrossRef] 
70. Hobbs, P.R.; Sayre, K.; Gupta, R. The role of conservation agriculture in sustainable agriculture. Philos. Trans. R. Soc. B Biol. Sci. 2008, 363, 543-555. [CrossRef] [PubMed]

71. Giller, K.E.; Witter, E.; Corbeels, M.; Tittonell, P. Conservation agriculture and smallholder farming in Africa: The heretics' view. Soil Tillage Res. 2009, 114, 23-34. [CrossRef]

72. Jat, R.A.; Wani, P.S.; Saharwat, K.L. Conservation agriculture in the semi-arid tropics: Prospects and problems. Advan. Agron. 2012, 117, 192-273.

73. Peterson, J.M.; Ding, Y. Economic adjustments to groundwater depletion in the high plains: Do water-saving irrigation systems save water? Am. J. Agric. Econ. 2005, 87, 147-159. [CrossRef]

74. Zhang, J.P.; Tian, H.Y.; Guo, B.T. Determination method of water saving threshold in arid area. Procedia Eng. 2012, $28,873-876$.

75. Masih, I.; Giordano, M. Constraints and opportunities for water savings and increasing productivity through Resource Conservation Technologies in Pakistan. Agric. Ecosyst. Environ. 2014, 187, 106-115.

76. Rizwan, M.; Bakhsh, A.; Li, X.; Anjum, L.; Jamal, K.; Hamid, S. Evaluation of the impact of water management technologies on water savings in the lower chenab canal command area, Indus River Basin. Water 2018, 10, 681. [CrossRef]

77. Foster, S.; Tuinhof, A.; Kemper, K.; Garduno, H.; Nanni, M. Groundwater Management Strategies: Facets of the Integrated Approach; (No30091, p. 1); The World Bank: Washington, DC, USA, 2003.

78. Seckler, D.; Molden, D.; Sakthivadivel, R. The concept of efficiency in water resources management and policy. Water Product. Agric. Limits Oppor. Improv. 2003, 1, 37-51. Available online: https://hdl.handle.net/10568/36992 (accessed on 4 September 2019).

79. Harrington, L.; Erenstein, O. Conservation agriculture and resource conserving technologies: A global perspective. Agromeridian 2005, 1, 32-43.

80. FAO (Food and Agriculture Organization of the United Nations). Conservation Agriculture. 2007. Available online: http: / / www.fao.org/conservation-agriculture/en/ (accessed on 12 September 2020).

81. FAO (Food and Agriculture Organization of the United Nations). 2012. Available online: http://www.fao.org/ag/ca/6c.html (accessed on 4 September 2019).

82. Hobbs, P.R. Conservation agriculture: What is it and why is it important for future sustainable food production? J. Agric. Sci. 2007, 145, 127-137. [CrossRef]

83. Pokharel, D.; Jha, R.K.; Tiwari, T.P.; Gathala, M.K.; Shrestha, H.K.; Panday, D. Is conservation agriculture a potential option for cereal-based sustainable farming system in the Eastern Indo-Gangetic Plains of Nepal? Cogent Food Agric. $2018,4,1557582$.

84. Dumanski, J.; Peiretti, R.; Benetis, J.; McGarry, D.; Pieri, C. The paradigm of conservation tillage. Proc. World Assoc. Soil Water Conserv. 2006, 1, 58-64.

85. Jat, R.K.; Sapkota, T.B.; Singh, R.G.; Jat, M.L.; Kumar, M.; Gupta, R.K. Seven years of conservation agriculture in a rice-wheat rotation of Eastern Gangetic Plains of South Asia: Yield trends and economic profitability. Field Crops Res. 2014, 164, 199-210. [CrossRef]

86. FAO (Food and Agriculture Organization of the United Nations). Conservation Agriculture; Food and Agriculture Organization: Rome, Italy, 2018. Available online: http:/ /www.fao.org/conservationagriculture/en/ (accessed on 27 May 2018).

87. Islam, S.; Gathala, M.K.; Tiwari, T.P.; Timsina, J.; Laing, A.M.; Maharjan, S.; Chowdhury, A.K.; Bhattacharya, P.M.; Dhar, T.; Mitra, B.; et al. Conservation agriculture based sustainable intensification: Increasing yields and water productivity for smallholders of the Eastern Gangetic Plains. Field Crops Res. 2019, 238, 1-17. [CrossRef]

88. Kassam, A.; Friedrich, T.; Derpsch, R. Global spread of conservation agriculture. Int. J. Environ. Stud. 2019, 76, 29-51. [CrossRef]

89. CTIC (Conservation Tillage Information Center). National Crop Residue Management Survey; NACD's Conservation Technology Information Center: West Lafayette, IN, USA, 2004.

90. Goss, M.J.; Carvalho, M.; Brito, I. Functional Diversity of Mycorrhiza and Sustainable Agriculture: Management to Overcome Biotic and Abiotic Stresses; Academic Press: Cambridge, MA, USA, 2017.

91. Bhan, S.; Behera, U.K. Conservation agriculture in India-Problems, prospects and policy issues. Int. Soil Water Conserv. Res. 2014, 2, 1-12. [CrossRef]

92. Sinha, A.K.; Ghosh, A.; Dhar, T.; Bhattacharya, P.M.; Mitra, B.; Rakesh, S.; Paneru, P.; Shrestha, S.R.; Manandhar, S.; Beura, K.; et al. Trends in key soil parameters under conservation agriculture-based sustainable intensification farming practices in the Eastern Ganga Alluvial Plains. Soil Res. 2019, 57, 883-893. [CrossRef]

93. Kassam, A.; Friedrich, T.; Shaxson, F.; Pretty, J. The spread of Conservation Agriculture: Justification, sustainability and uptake. Int. J. Agric. Sustain. 2009, 7, 292-320. [CrossRef]

94. Li, Y.; Šimůnek, J.; Wang, J.; Yuan, J.; Zhang, W. Modeling of soil water regime and water balance in a transplanted rice field experiment with reduced irrigation. Water 2017, 9, 248. [CrossRef]

95. Perry, C.; Steduto, P.; Karajeh, F. Does Improved Irrigation Technology Save Water? A Review of the Evidence; Food and Agriculture Organization of the United Nations: Cairo, Egypt, 2017; p. 42.

96. Iwasaki, Y.; Ozaki, M.; Nakamura, K.; Horino, H.; Kawashima, S. Relationship between increment of groundwater level at the beginning of irrigation period and paddy filed area in the Tedori River Alluvial Fan Area, Japan. Paddy Water Environ. 2013, 11, 551-558. [CrossRef]

97. Fujihara, Y.; Yamada, R.; Oda, M.; Fujii, H.; Ito, O.; Kashiwagi, J. Effects of puddling on percolation and paddy yields in rainfed lowland paddy cultivation: Case study in Khammouane Province, Central Laos. Agric. Sci. 2013, 4, 360-368. [CrossRef] 
98. Li, Y.; Šimůnek, J.; Jing, L.; Zhang, Z.; Ni, L. Evaluation of water movement and water losses in a direct-seeded-paddy field experiment using Hydrus-1D. Agric. Water Manag. 2014, 142, 38-46. [CrossRef]

99. Bonsor, H.C.; MacDonald, A.M.; Ahmed, K.M.; Burgess, W.G.; Basharat, M.; Calow, R.C.; Dixit, A.; Foster, S.S.D.; Gopal, K.; Lapworth, D.J.; et al. Hydrogeological typologies of the Indo-Gangetic basin alluvial aquifer, South Asia. Hydrogeol. J. 2017, 25, 1377-1406. [CrossRef]

100. Adarsh, S.; Thomas, G. Artificial groundwater recharge through rice (Oryza sativa L.) cultivation: A systematic review. Int. J. Chem. Stud. 2019, 7, 1856-1860.

101. Rushton, K.R.; Zaman, M.A.; Hasan, M. Monitoring groundwater heads and estimating recharge in multi-aquifer systems illustrated by an irrigated area in North-West Bangladesh. Sustain. Water Resour. Manag. 2020, 6, 1-12. [CrossRef]

102. Xie, H.; Longuevergne, L.; Ringler, C.; Scanlon, B.R. Integrating groundwater irrigation into hydrological simulation of India: Case of improving model representation of anthropogenic water use impact using GRACE. J. Hydrol. Reg. Stud. 2020, $29,100681$. [CrossRef]

103. Molden, D.; Fraiture, C.D.E. Comprehensive assessment of water management in agriculture. Agric. Water Manag. 2010, 97, 493-578.

104. Mainuddin, M.; Maniruzzaman, M.; Alam, M.M.; Mojid, M.A.; Schmidt, E.J.; Islam, M.T.; Scobie, M. Water usage and productivity of Boro rice at the field level and their impacts on the sustainable groundwater irrigation in the North-West Bangladesh. Agric. Water Manag. 2020, 240, 106294. [CrossRef]

105. Foster, S.; Chilton, J.; Moench, M.; Cardy, F.; Schiffler, M. Groundwater in Rural Development: Facing the Challenges of Supply and Resource Sustainability; Technical Paper 463; World Bank: Washington, DC, USA, 2000; p. 98.

106. Humphreys, E.; Meisner, C.; Gupta, R.; Timsina, J.; Beecher, H.G.; Lu, T.Y.; Yadvinder-Singh, Y.S.; Gill, M.A.; Masih, I.; Guo, Z.J.; et al. Water saving in rice-wheat systems. Plant Product. Sci. 2005, 8, 242-258. [CrossRef]

107. LaHue, G.T.; Linquist, B.A. The contribution of percolation to water balances in water-seeded rice systems. Agric. Water Manag. 2021, 243, 106445. [CrossRef]

108. Bouman, B.A.M.; Tuong, T.P. Field water management to save water and increase its productivity in irrigated lowland rice. Agric. Water Manag. 2001, 49, 11-30. [CrossRef]

109. Hira, G.S.; Rachhpal, S.; Kukal, S.S. Soil matric suction: A criterion for scheduling irrigation to rice (Oryza sativa). Indian J. Agric. Sci. 2002, 72, 236-237.

110. Humphreys, E.; Kukal, S.S.; Amanpreet, K.; Sudhir, T.; Sudhir, Y.; Yadvinder, S.; Balwinder, S.; Timsina, J.; Dhillon, S.S.; Prashar, A.; et al. Permanent Beds for Rice-Wheat Systems in Punjab, India 2: Water Balance and Soil Water Dynamics. In $A C I A R$ Proceedings Series; ACIAR: Canberra, Australia, 2008; pp. 37-61.

111. Zhang, H.; Xue, Y.; Wang, Z.; Yang, J.; Zhang, J. Alternate wetting and moderate soil drying improves root and shoot growth in rice. Crop Sci. 2009, 49, 2246-2260. [CrossRef]

112. Feng, Z.Z.; Wang, X.K.; Feng, Z.W. Soil N and salinity leaching after the autumn irrigation and its impact on groundwater in Hetao Irrigation District, China. Agric. Water Manag. 2005, 71, 131-143. [CrossRef]

113. Berbel, J.; Gutiérrez-Martín, C.; Rodríguez-Díaz, J.A.; Camacho, E.; Montesinos, P. Literature review on re-bound effect of water saving measures and analysis of a Spanish case study. Water Resour. Manag. 2015, 29, 663-678. [CrossRef]

114. Loch, A.; Adamson, D. Drought and the Re-bound Effect: A Murray-Darling Basin Example. Nat. Hazards 2015, 79, 1429-1449. [CrossRef]

115. Koech, R.; Langat, P. Improving irrigation water use efficiency: A review of advances, challenges and opportunities in the Australian context. Water 2018, 10, 1771. [CrossRef]

116. Linstead, C. The contribution of improvements in irrigation efficiency to environmental flows. Front. Environ. Sci. 2018, 6, 48. [CrossRef]

117. European Commission (EC). A Blueprint to Safeguard Europe's Water Resources, Brussels. Available online: http:/ / eur-lex. europa.eu/legal-content/EN/TXT/?uri=CELEX:52012DC0673 (accessed on 12 September 2020).

118. Foster, S.; Pulido-Bosch, A.; Vallejos, Á.; Molina, L.; Llop, A.; MacDonald, A.M. Impact of irrigated agriculture on groundwaterrecharge salinity: A major sustainability concern in semi-arid regions. Hydrogeol. J. 2018, 26, 2781-2791. [CrossRef]

119. Rahman, M.A.; Roehrig, J. Estimation of Potential Recharge and Groundwater Resource Assessment-A Case Study in Low Barind Area, Bangladesh. In Conference on International Agricultural Research for Development; University of Bonn: Bonn, Germany, 2006; pp. 11-13.

120. Michael, H.A.; Voss, C.I. Controls on groundwater flow in the Bengal Basin of India and Bangladesh: Regional modeling analysis. Hydrogeol. J. 2009, 17, 1561-1577. [CrossRef]

121. Winter, T.C.; Harvey, J.W.; Franke, O.L.; Alley, W.M. Ground Water and Surface Water: A Single Resource. USGS Circular 1139; US Geological Survey: Denver, CO, USA, 1998.

122. Fullagar, I.; Brodie, R.; Sundaram, B.; Hostetler, S.; Baker, P. Managing Connected Surface Water and Groundwater Resources. In Science for Decision Makers; Australian Government, Bureau of Rural Sciences: Canberra, Australia, 2006.

123. Brkić, Ž.; Kuhta, M.; Larva, O.; Gottstein, S. Groundwater and connected ecosystems: An overview of groundwater body status assessment in Croatia. Environ. Sci. Eur. 2019, 31, 75. [CrossRef]

124. Loeve, R.; Dong, B.; Molden, D. Field-Level Water Savings in the Zhanghe Irrigation System and the Impact at the System Level. In Proceedings of the International Workshop on Water-wise Rice Production, Los Baños, Philippines, 8-11 April $2002 ;$ p. 356. 
125. Arif, C.; Setiawan, B.I.; Mizoguchi, M. Estimation of water balance components in paddy fields under non-flooded irrigation regimes by using excel solver. J. Agron. 2012, 11, 53-59. [CrossRef]

126. Qureshi, M.E.; Grafton, R.Q.; Kirby, M.; Hanjra, M.A. Understanding irrigation water use efficiency at different scales for better policy reform: A case study of the Murray-Darling Basin, Australia. Water Policy 2011, 13, 1-17. [CrossRef]

127. Ahmad, M.U.D.; Turral, H.; Masih, I.; Giordano, M.; Masood, Z. Water Saving Technologies: Myths and Realities Revealed in Pakistan's Rice-Wheat Systems; International Water Management Institute (IWMI): Anand, India, 2007.

128. Mechlem, K. Groundwater Governance: The Role of Legal Frameworks at the Local and National Level - Established Practice and Emerging Trends. J. Water 2016, 347, 347. [CrossRef]

129. Bhattacharjee, S.; Saha, B.; Saha, B.; Uddin, M.S.; Panna, C.H.; Bhattacharya, P.; Saha, R. Groundwater governance in Bangladesh: Established practices and recent trends. Groundwater for Sust. Dev. 2019, 8, 69-81. [CrossRef]

130. Qureshi, A.S.; Ahmad, Z.U.; Timothy, J.K. Moving from resource development to resource management: Problems, prospects and policy recommendations for sustainable groundwater management in Bangladesh. Water Resour. Manag. 2015, 29, $4269-4283$. [CrossRef]

131. Giordano, M. Global groundwater? Issues and solutions. Annu. Rev. Environ. Resour. 2009, 34, 153-178. [CrossRef]

132. Theesfeld, I. Institutional challenges for national groundwater governance: Policies and issues. Ground Water 2010, 48, 131-142. [CrossRef] [PubMed]

133. Sophocleous, M.A. From safe yield to sustainable development of water resources and the Kansas experience. J. Hydrol. 2000, 235, 27-43. [CrossRef]

134. Aeschbach-Hertig, W.; Gleeson, T. Regional strategies for the accelerating global problem of groundwater depletion. Nat. Geosci. 2012, 5, 853-861. [CrossRef]

135. Bhushan, L.; Ladha, J.K.; Gupta, R.K.; Singh, S.; Tirol-Padre, A.; Saharawat, Y.S.; Gathala, M.; Pathak, H. Saving of water and labor in a rice-wheat system with no tillage and direct seeding technologies. Agron. J. 2007, 99, 1288-1296. [CrossRef]

136. Gathala, M.K.; Timsina, J.; Islam, S.; Rahman, M.; Hossain, I.; Rashid, H.-A.; Ghosh, A.K.; Krupnik, T.J.; Tiwari, T.P.; McDonald, A. Conservation agriculture based tillage and crop establishment options can maintain farmers' yields and increase profits in South Asia's rice-maize systems: Evidence from Bangladesh. Field Crops Res. 2015, 172, 85-98. [CrossRef]

137. Parihar, C.M.; Jat, S.L.; Singh, A.K.; Ghosh, A.; Rathore, N.S.; Kumar, B.; Pradhan, S.; Majumdar, K.; Satyanarayana, T.; Jat, M.L.; et al. Effects of precision conservation agriculture in a maize-wheat-mungbean rotation on crop yield, water use and radiation conversion under a semiarid agro-ecosystem. Agric. Water Manag. 2017, 192, 306-319. [CrossRef]

138. Gathala, M.K.; Ladha, J.K.; Saharawat, Y.S.; Kumar, V.; Kumar, V.; Sharma, P.K. Effect of tillage and crop establishment methods on physical properties of a medium textured soil under a seven-year rice-wheat rotation. Soil Sci. Soc. Am. J. 2011, 75, 1851-1862. [CrossRef]

139. Parihar, C.M.; Yadav, M.R.; Jat, S.L.; Singh, A.K.; Kumar, B.; Pradhan, S.; Chakraborty, D.; Jat, M.L.; Jat, R.K.; Saharawat, Y.S.; et al. Long term effect of conservation agriculture in maize rotations on total organic carbon, physical and biological properties of a sandy loam soil in north-western Indo-Gangetic Plains. Soil Tillage Res. 2016, 161, 116-128.

140. Singh, V.K.; Singh, Y.; Dwivedi, B.S.; Singh, K.S.; Majumdar, K.; Jat, M.L.; Mishra, R.P.; Rani, M. Soil physical properties, yield trends and economics after five years of conservation agriculture based rice-maize system in north-western India. Soil Tillage Res. 2016, 155, 133-148.

141. Clemmens, A.J.; Allen, R.G. Impact of agricultural water conservation on water availability. In Impacts of Global Climate Change; ASCE: Reston, VA, USA, 2005; pp. 1-14.

142. Jat, M.L.; Gathala, M.K.; Ladha, J.K.; Saharawat, Y.S.; Jat, A.S.; Kumar, V.; Sharma, S.K.; Kumar, V.; Gupta, R. Evaluation of precision land leveling and double zero-till systems in the rice-wheat rotation: Water use, productivity, profitability and soil physical properties. Soil Tillage Res. 2009, 105, 112-121.

143. Nangia, V.; Ahmad, M.D.; Jiantao, D.; Changrong, Y.; Hoogenboom, G.; Xurong, M.; Wenqing, H.; Shuang, L.; Qin, L. Effects of conservation agriculture on land and water productivity of rainfed maize in the Yellow River Basin, China. Int. J. Agric. Biol. Eng. 2010, 3, 5-18.

144. Pandey, D.; Agrawal, M.; Bohra, J.S. Greenhouse gas emissions from rice crop with different tillage permutations in rice-wheat system. Agric. Ecosys. Environ. 2012, 159, 133-144. [CrossRef]

145. Saharawat, Y.S.; Ladha, J.K.; Pathak, H.; Gathala, M.K.; Chaudhary, N.; Jat, M.L. Simulation of resource-conserving technologies on productivity, income and greenhouse gas GHG emission in rice-wheat system. J. Soil Sci. Environ. Manag. 2012, 3, 9-22.

146. Wang, J.; Rothausen, S.G.; Conway, D.; Zhang, L.; Xiong, W.; Holman, I.P.; Li, Y. China's water-energy nexus: Greenhouse-gas emissions from groundwater use for agriculture. Environ. Res. Lett. 2012, 7, 014035. [CrossRef]

147. Reicosky, D.C. Carbon sequestration and environmental benefits from no-till systems. In No-Till Farming Systems; Special Publication No. 3; Goddard, T., Zoebisch, M.A., Gan, Y.T., Ellis, W., Watson, A., Sombatpanit, S., Eds.; World Association of Soil and Water Conservation (WASWC): Bangkok, Thailand, 2008; pp. 43-58.

148. Nelson, R.G.; Hellwinckel, C.M.; Brandt, C.C.; West, T.O.; De La Ugarte, T.; Marland, G. Energy uses and carbon dioxide emissions from cropland production in the United States, 1990-2004. J. Environ. Qual. 2009, 38, 418-425. [CrossRef]

149. West, O.T.; Post, W.M. Soil organic carbon sequestration rates by tillage and crop rotation: A global data analysis. Soil Sci. Soc. Am. J. 2002, 66, 1930-1946. [CrossRef] 
150. Blanco-Canqui, H.; Lal, R. No-tillage and carbon sequestration: An on-farm assessment. Soil Sci. Soc. Am. 2008, $72,693-701$. [CrossRef]

151. CTIC (Conservation Tillage Information Center)/FAO. Mitigating Climate Change: Conservation Agriculture Stores Soil Carbon. In Proceedings of the Recommendations of the Conservation Agriculture Carbon Offset Consultation, West Lafayette, IN, USA, 28-30 October 2008. Available online: http:/ / www.fao.org/ag/ca (accessed on 10 September 2019).

152. Hobbs, P.R.; Giri, G.S.; Grace, P. Reduced and Zero Tillage Options for the Establishment of Wheat after Rice in South Asia; Rice-Wheat Consortium Paper Series 2; Rice-Wheat Consortium: New Delhi, India, 1997.

153. Gupta, R.K.; Naresh, R.K.; Hobbs, P.R.; Ladha, J.K. Adopting Conservation Agriculture in the Rice-Wheat System of the IndoGangetic Plains: New Opportunities for Saving Water. In Water Wise Rice Production. Water Wise Rice Production, Proceedings of the International Workshop on Water Wise Rice Production, Los Banos, Philippines, April 8-11, 2002; IRRI: Laguna, Philippines, 2002; pp. 207-222.

154. Hobbs, P.R.; Gupta, R.K. Rice-Wheat Cropping Systems in the Indo-Gangetic Plains: Issues of Water Productivity in Relation to New Re-source-Conserving Technologies. In Water Productivity in Agriculture: Limits and Opportunities for Improvement; Kijne, J.W., Barker, R., Molden, D., Eds.; CABI Publications: Wallingford, UK, 2003.

155. Erenstein, O.; Farooq, U.; Malik, R.K.; Sharif, M. On-farm impacts of zero tillage wheat in South Asia's rice-wheat systems. Field Crops Res. 2008, 105, 240-252. [CrossRef]

156. Mahboubi, A.A.; Lal, R.; Fausey, N.R. Twenty-eight years of tillage effects on two soils in Ohio. Soil Sci. Soc. Am. J. 1993, 57, 506-512. [CrossRef]

157. Halvorson, A.D.; Peterson, G.A.; Reule, C.A. Tillage system and crop rotation effects on dryland crop yields and soil carbon in the Central Great Plains. Agron. J. 2002, 94, 429-1436. [CrossRef]

158. Eze, S.; Dougill, A.J.; Banwart, S.A.; Hermans, T.D.; Ligowe, I.S.; Thierfelder, C. Impacts of conservation agriculture on soil structure and hydraulic properties of Malawian agricultural systems. Soil Tillage Res. 2020, 201, 104639.

159. Verhulst, N.; Govaerts, B.; Verachtert, E.; Castellanos-Navarrete, A.; Mezzalama, M.; Wall, P.; Deckers, J.; Sayre, K.D. Conservation Agriculture, Improving Soil Quality for Sustainable Production Systems. In Advances in Soil Science: Food Security and Soil Quality; CRC Press: Boca Raton, FL, USA, 2010; pp. 137-208.

160. Lal, R. Long-term tillage and maize monoculture effects on a tropical Alfisol in western Nigeria. I. Crop yield and soil physical properties. Soil Tillage Res. 1997, 42, 145-160.

161. Roper, M.M.; Ward, P.R.; Keulen, A.F.; Hill, J.R. Under no-tillage and stubble retention, soil water content and crop growth are poorly related to soil water repellency. Soil Tillage Res. 2013, 126, 143-150.

162. Singh, A.; Phogat, V.K.; Dahiya, R.; Batra, S.D. Impact of long-term zero till wheat on soil physical properties and wheat productivity under rice-wheat cropping system. Soil Tillage Res. 2014, 140, 98-105.

163. Somasundaram, J.; Reeves, S.; Wang, W.; Heenan, M.; Dalal, R. Impact of 47 years of no-tillage and stubble retention on soil aggregation and carbon distribution in a Vertisol. Land Degrad. Dev. 2017, 28, 1589-1602.

164. Alvarez, R. A review of nitrogen fertilizer and conservation tillage effects on soil organic carbon storage. Soil Use Manag. 2005, 21, 38-52. [CrossRef]

165. Dalal, R.C.; Allen, D.E.; Wang, W.J.; Reeves, S.; Gibson, I. Organic carbon and total nitrogen stocks in a Vertisol following 40 years of no-tillage, crop residue retention and nitrogen fertilization. Soil Tillage Res. 2011, 112, 133-139.

166. Shaver, T.M.; Peterson, G.A.; Ahuja, L.R.; Westfall, D.G.; Sherrod, L.A.; Dunn, G. Surface soil properties after twelve years of dryland no-till management. Soil Sci. Soc. Am. J. 2002, 66, 1292-1303. [CrossRef]

167. Busari, M.A.; Kukal, S.S.; Kaur, A.; Bhatt, R.; Dulazi, A.A. Conservation tillage impacts on soil, crop and the environment. Int. Soil Water Conserv. Res. 2015, 3, 119-129. [CrossRef]

168. Pagliai, M.; Vignozzi, N.; Pellegrini, S. Soil structure and the effect of management practices. Soil Tillage Res. 2004, 79, 131-143.

169. Bissett, M.J.; O'Leary, G.J. Effects of conservation tillage on water infiltration in two soils in south-eastern Australia. Aust. J. Soil Res. 1996, 34, 299-308. [CrossRef]

170. McGarry, D.; Bridge, B.J.; Radford, B.J. Contrasting soil physical properties after zero and traditional tillage of an alluvial soil in the semi-arid subtropics. Soil Tillage Res. 2000, 53, 105-115.

171. Sayre, K.D.; Hobbs, P.R. The Raised-Bed System of Cultivation for Irrigated Production Conditions. In Sustainable Agriculture and the International Rice-Wheat System; Lal, R., Hobbs, P., Uphoff, N., Hansen, D.O., Eds.; Ohio State University: Columbus, OH, USA, 2004.

172. Allmaras, R.R.; Rickman, R.W.; Ekin, L.G.; Kimball, B.A. Chiseling influences on soil hydraulic properties. Soil Sci. Soc. Am. J. 1977, 41, 796-803. [CrossRef]

173. Benjamin, J.G. Tillage effects on near-surface soil hydraulic properties. Soil Tillage Res. 1993, 26, $277-288$.

174. De Vita, P.; Di Paolo, E.; Fecondo, G.; Di Fonzo, N.; Pisante, M. No-tillage and conventional tillage effects on durum wheat yield, grain quality and soil moisture content in Southern Italy. Soil Tillage Res. 2007, 92, 69-78.

175. Kahlown, M.A.; Azam, M.; Kemper, W.D. Soil management strategies for rice-wheat rotations in Pakistan's Punjab. J. Soil Water Conserv. 2006, 61, 40-44.

176. Farooq, U.; Muhammad, S.; Erenstein, O. Adoption and Impacts of Zero-Tillage in the Rice-Wheat Zone of Irrigated Punjab, Pakistan; CIMMYT and the Rice-Wheat Consortium for the Indo-Gangetic Plains: New Delhi, India, 2007; p. 69.

177. Gupta, R.; Seth, A. A review of resource conserving technologies for sustainable management of the rice-wheat cropping systems of the Indo-Gangetic plains (IGP). Crop Protect. 2007, 26, 436-447. [CrossRef] 
178. Jat, R.K.; Singh, R.G.; Kumar, M.; Jat, M.L.; Parihar, C.M.; Bijarniya, D.; Sutaliya, J.M.; Jat, M.K.; Parihar, M.D.; Kakraliya, S.K.; et al. Ten years of conservation agriculture in a rice-maize rotation of Eastern Gangetic Plains of India: Yield trends, water productivity and economic profitability. Field Crops Res. 2019, 232, 1-10. [CrossRef]

179. Mohammad, A.; Sudhishri, S.; Das, T.K.; Singh, M.; Bhattacharyya, R.; Dass, A.; Khanna, M.; Sharma, V.K.; Dwivedi, N.; Kumar, M. Water balance in direct-seeded rice under conservation agriculture in north-western indo-gangetic plains of India. Irrig. Sci. 2018, 36, 381-393. [CrossRef]

180. FAO (Food and Agriculture Organization of the United Nations). Global Diagnostic of Groundwater Governance-Thematic Papers. 2016. Available online: http://www.groundwatergovernance.org/resources/thematic-papers/en/ (accessed on 12 September 2020).

181. Gleick, P.H.; Christian-Smith, J.; Cooley, H. Water-use efficiency and productivity: Rethinking the basin approach. Water Int. 2011, 36, 784-798. [CrossRef]

182. Johnson, N.; Revenga, C.; Echeverria, J. Managing Water for People and Nature. Science 2001, 292, 1071-1072. [CrossRef]

183. Mao, Z. Water Efficient Irrigation and Environmentally Sustainable Irrigated Rice Production in China. International Commission on Irrigation and Drainage. 2001. Available online: https://www.icid.org/wat_mao.pdf (accessed on 12 September 2020).

184. Liang, Y.; Li, F.; Nong, M.; Luo, H.; Zhang, J. Microbial activity in paddy soil and water use efficiency of rice as affected by irrigation method and nitrogen level. Comm. Soil Sci. Plant Anal. 2015, 47, 19-31. [CrossRef]

185. Tan, X.; Shao, D.; Liu, H.; Yang, F.; Xiao, C.; Yang, H. Effects of alternate wetting and drying irrigation on percolation and nitrogen leaching in paddy fields. Paddy Water Environ. 2013, 11, 381-395. [CrossRef]

186. Ye, Y.; Liang, X.; Chen, Y.; Liu, J.; Gu, J.; Guo, R.; Li, L. Alternate wetting and drying irrigation and controlled-release nitrogen fertilizer in late-season rice. Effects on dry matter accumulation, yield, water and nitrogen use. Field Crops Res. 2013, 144, 212-224. [CrossRef]

187. Prathapar, S.A.; Qureshi, A.S. Modelling the effects of deficit irrigation on soil salinity, depth to water table and transpiration in semi-arid zones with monsoonal rains. Water Resour. Dev. 1999, 15, 141-159. [CrossRef]

188. Bouman, B.A.M.; Feng, L.; Tuong, T.P.; Lu, G.; Wang, H.; Feng, Y. Exploring options to grow rice using less water in northern China using a modelling approach II. Quantifying yield, water balance components and water productivity. Agric. Water Manag. 2007a, 88, 23-33. [CrossRef]

189. Kato, Y.; Okami, M. Root morphology, hydraulic conductivity and plant water relations of high-yielding rice grown under aerobic conditions. Ann. Bot. 2011, 108, 575-583. [CrossRef] [PubMed]

190. El-Sadek, A. Water use optimisation based on the concept of partial rootzone drying. Ain Shams Eng. J. 2014, 5, 55-62. [CrossRef]

191. Zhang, Z.; Zhang, S.; Yang, J.; Zhang, J. Yield, grain quality and water use efficiency of rice under non-flooded mulching cultivation. Field Crops Res. 2008, 108, 71-81. [CrossRef]

192. Feng, L.P.; Bouman, B.A.M.; Tuong, T.P.; Cabangon, R.J.; Li, Y.L.; Lu, G.A.; Feng, Y.H. Exploring options to grow rice using less water in northern China using a modeling approach - 1. Field experiments and model evaluation. Agric. Water Manag. 2007, 88, 1-13. [CrossRef]

193. Zaman, A.; Gangarani, T. Aerobic Rice Cultivation on Adoption of Water Saving Technologies and Improving Agronomic Practices during Summer Season under Conservation Agriculture. In Proceedings of the Conference on Conservation Agriculture for Smallholders in Asia and Africa, Mymensingh, Bangladesh, 7-11 December 2014; Vance, W., Bell, R.W., Haque, M.E., Eds.; 2014. Published as an E-book.

194. Kader, M.A.; Senge, M.; Mojid, M.A.; Onishi, T.; Ito, K. Effects of plastic-hole mulching on effective rainfall and readily available soil moisture under soybean (Glycine max) cultivation. Paddy Water Environ. 2017, 15, 659-668. [CrossRef]

195. Kader, M.A.; Nakamura, K.; Senge, M.; Mojid, M.A.; Kawashima, S. Numerical simulation of water-and heat-flow regimes of mulched soil in rain-fed soybean field in central Japan. Soil Tillage Res. 2019, 191, 142-155.

196. Igbadun, H.E.; Salim, B.A.; Tarimo, A.K.P.R.; Mahoo, H.F. Effects of deficit irrigation scheduling on yields and soil water balance of irrigated maize. Irrig. Sci. 2008, 27, 11-23. [CrossRef]

197. Karam, F.; Lahoud, R.; Masaad, R.; Kabalan, R.; Breidi, J.; Chalita, C.; Rouphael, Y. Evapotranspiration, seed yield and water use efficiency of drip irrigated sunflower under full and deficit irrigation conditions. Agric. Water Manag. 2007, 90, 213-223. [CrossRef]

198. Gowing, J.W.; Rose, D.A.; Ghamarnia, H. The effect of salinity on water productivity of wheat under deficit irrigation above shallow groundwater. Agric. Water Manag. 2009, 96, 517-524. [CrossRef]

199. Zhou, Y. A critical review of groundwater budget myth, safe yield and sustainability. J. Hydrol. 2009, 370, 207-213. [CrossRef]

200. Rao, S.S.; Tanwar, S.P.S.; Regar, P.L. Effect of deficit irrigation, phosphorous inoculation and cycocel spray on root growth, seed cotton yield and water productivity of drip irrigated cotton in arid environment. Agric. Water Manag. 2016, 169, 14-25. [CrossRef]

201. Babajimopoulos, C.; Panoras, A.; Georgoussis, H.; Arampatzisb, G.; Hatzigiannakisb, E.; Papamichail, D. Contribution to irrigation from shallow groundwater table under field conditions. Agric. Water Manag. 2007, 92, 205-210. [CrossRef]

202. Keller, A.; Keller, J.; Seckler, D. Integrated Water Resource Systems: Theory and Policy Implications; Research Report 3; International Water Management Institute: Colombo, Sri Lanka, 1996.

203. Ahmad, M.U.D.; Bastiaanssen, W.G.; Feddes, R.A. Sustainable use of groundwater for irrigation: A numerical analysis of the subsoil water fluxes. Irrigation and Drainage. J. Int. Comm. Irrig. Drain. 2002, 51, 227-241. [CrossRef] 
204. Tuong, T.P.; Bouman, B.A.M.; Mortimer, M. More rice, less water-integrated approaches for increasing water productivity in irrigated rice based systems in Asia. Plant Product. Sci. 2005, 8, 231-241. [CrossRef]

205. Huang, H.-C.; Liu, C.-W.; Chen, S.-K.; Chen, J.-S. Analysis of percolation and seepage through paddy bunds. J. Hydrol. 2003, 284, 13-25. [CrossRef]

206. Ahmad, M.D.; Kirby, M.; Islam, M.S.; Hossain, M.J.; Islam, M.M. Groundwater use for irrigation and its productivity: Status and opportunities for crop intensification for food security in Bangladesh. Water Resour. Manag. 2014, 28, 1415-1429. [CrossRef]

207. Acharjee, T.K.; van Halsema, G.; Ludwig, F.; Hellegers, P.; Supit, I. Shifting planting date of Boro rice as a climate change adaptation strategy to reduce water use. Agric. Syst. 2019, 168, 131-143. [CrossRef]

208. Khan, S.; Best, L.; Wang, B. Surface-Ground Water Interaction Model of the Murrumbidgee Irrigation Area; CSIRO Land and Water Technical Report 36/02; CSIRO Land and Water: Griffith, Australia, 2002.

209. Seckler, D. The Sardar Sarovar Project in India: A Commentary on the Report of the Independent Review. Water Resources and Irrigation Division (Discussion Paper 8); Winrock International: Arlington, VA, USA, 1992.

210. Seckler, D. The New Era of Water Resources Management: From 'Dry' to 'Wet' Savings; Research Report No. 1; International Irrigation Management Institute (IIMI): Colombo, Sri Lanka, 1996.

211. Frederiksen, H.D.; Perry, C. Needs and Priorities in Water-Related Research; Draft Paper; International Irrigation Management Institute (IIMI): Colombo, Sri Lanka, 1995.

212. Keller, A.; Keller, J.; Seckler, D. Integrated Water Resource Systems: Theory and Policy Implications; International Irrigation Management Institute (IIMI): Colombo, Sri Lanka, 1995.

213. Simons, G.W.H.; Bastiaanssen, W.G.M.; Cheema, M.J.M.; Ahmad, B.; Immerzeel, W.W. A novel method to quantify consumed fractions and non-consumptive use of irrigation water: Application to the Indus Basin Irrigation System of Pakistan. Agric. Water Manag. 2020, 236, 106174. [CrossRef]

214. Molden, D. Accounting for Water Use and Productivity; SWIM Paper 1; International Water Management Institute (IWMI): Colombo, Sri Lanka, 1997.

215. Garrick, D.; Bark, R.; Connor, J.; Banerjee, O. Environmental water governance in federal rivers: Opportunities and limits for subsidiarity in Australia's Murray-Darling River. Water Policy 2012, 14, 915-936. [CrossRef]

216. Jiang, G.; Wang, Z. Scale effects of ecological safety of water-saving irrigation: A case study in the arid inland river basin of Northwest China. Water 2019, 11, 1886. [CrossRef]

217. Sandhu, B.S.; Khera, K.L.; Prihar, S.S.; Singh, B. Irrigation needs and yield of rice on a sandy-loam soil as affected by continuous and intermittent submergence. Indian J. Agric. Sci. 1980, 50, 492-496.

218. Li, Y.; Barker, R. Increasing water productivity for paddy irrigation in China. Paddy Water Environ. 2004, 2, 187-193. [CrossRef]

219. Bouman, B.A.M.; Lampayan, R.M.; Tuong, T.P. Water Management in Irrigated Rice: Coping with Water Scarcity; International Rice Research Institute, IRRI: Los Banos, Philippines, 2007.

220. Sattar, M.A.; Maniruzzaman, M.I.; Kashem, M.A. National Workshop Proceedings on AWD Technology for Rice Production in Bangladesh; Bangladesh Rice Research Institute: Gazipur, Bangladesh, 2009; p. 54.

221. Li, T.; Humphreys, E.; Gill, G.; Kukal, S.S. Evaluation and application of ORYZA2000 for irrigation scheduling of puddled transplanted rice in North-West India. Field Crops Res. 2011, 122, 104-117.

222. Xu, J.; Wei, Q.; Yu, Y.; Peng, S.; Yang, S. Influence of water management on the mobility and fate of copper in rice field soil. J. Soils Sediments 2013, 13, 1180-1188. [CrossRef]

223. Chen, Y.; Zhang, G.; Xu, Y.J.; Huang, Z. Influence of irrigation water discharge frequency on soil salt removal and rice yield in a semi-arid and saline-sodic area. Water 2013, 5, 578-592. [CrossRef]

224. Chivenge, P.; Angeles, O.; Hadi, B.; Acuin, C.; Connor, M.; Stuart, A.; Puskur, R.; Johnson-Beebout, S. Ecosystem Services in Paddy Rice Systems. In The Role of Ecosystem Services in Sustainable Food Systems; Academic Press: Cambridge, MA, USA, 2020; pp. 181-201.

225. Sudo, M.; Goto, Y.; Iwama, K.; Hida, Y. Herbicide discharge from rice paddy fields by surface runoff and percolation flow: A case study in paddy fields in the Lake Biwa basin, Japan. J. Pestic. Sci. 2018, 43, 24-32. [CrossRef] [PubMed]

226. Li, C.; Salas, W.; De Angelo, B.; Rose, S. Assessing alternatives for mitigating net greenhouse gas emissions and increasing yields from rice production in China over the next twenty years. J. Environ. Qual. 2006, 35, 1554-1565. [CrossRef] [PubMed]

227. Wassmann, R.; Nelson, G.C.; Peng, S.B.; Sumfleth, K.; Jagadish, S.V.K.; Hosen, Y.; Rosegrant, M.W. Rice and Global Climate Change. In Rice in the Global Economy: Strategic Research and Policy Issues for Food Security; Pandley, S., Byerlee, D., Dawe, D., Dobermann, A., Mohanty, S., Rozelle, S., Eds.; International Rice Research Institute: Los Baños, Philippines, 2010 ; pp. 411-432.

228. Das, S.; Chou, M.-L.; Jean, J.-S.; Liu, C.-C.; Yang, H.-J. Water management impacts on arsenic behavior and rhizosphere bacterial communities and activities in a rice agro-ecosystem. Sci. Total Environ. 2016, 542, 642-652. [CrossRef] [PubMed]

229. Linquist, B.; Anders, M.M.; Adviento-Borbe, M.A.A.; Chaney, R.L.; Nalley, L.L.; DaRoda, E.F.F.; Van Kessel, C. Reducing greenhouse gas emissions, water use, and grain arsenic levels in rice systems. Glob. Chang. Biol. 2014, 21, 407-417. [CrossRef]

230. Kürschner, E.; Henschel, C.; Hildebrandt, T.; Jülich, E.; Leineweber, M.; Paul, C. Water Saving in Rice Production-Dissemination, Adoption and Short Term Impacts of Alternate Wetting and Drying (AWD) in Bangladesh; SLE Publication Series S 241; Zerbe Druck \& Werbung: Berlin, Germany, 2010.

231. Nalley, L.L.; Linquist, B.; Kovacs, K.F.; Anders, M.M. The economic viability of alternate wetting and drying irrigation in Arkansas rice production. Agron. J. 2015, 107, 579-587. [CrossRef] 
232. Rothenberg, S.E.; Anders, M.; Ajami, N.J.; Petrosino, J.F.; Balogh, E. Water management impacts rice methylmercury and the soil microbiome. Sci. Total Environ. 2016, 572, 608-617. [CrossRef]

233. Jalota, S.K.; Singh, K.B.; Chahal, G.B.S.; Gupta, R.K.; Chakraborty, S.; Sood, A.; Ray, S.S.; Panigrahy, S. Integrated effect of transplanting date, cultivar and irrigation on yield, water saving and water productivity of rice (Oryza sativa L.) in Indian Punjab: Field and simulation study. Agric. Water Manag. 2009, 96, 1096-1104. [CrossRef]

234. Neumann, R.B.; Polizzotto, M.L.; Badruzzaman, A.B.M.; Ali, M.A.; Zhang, Z.; Harvey, C.F. Hydrology of a groundwater-irrigated rice field in Bangladesh: Seasonal and daily mechanisms of infiltration. Water Resour. Res. 2009, 45. [CrossRef]

235. Walker, S.H.; Rushton, K.R. Verification of lateral percolation losses from irrigated rice fields by a numerical-model. J. Hydrol. 1984, 71, 335-351. [CrossRef]

236. Tuong, T.P.; Wopereis, M.C.S.; Marquez, J.A.; Kropff, M.J. Mechanisms and control of percolation losses in irrigated puddled rice fields. Soil Sci. Soc. Am. J. 1994, 58, 1794-1803. [CrossRef]

237. Patil, M.D.; Das, B.S.; Bhadoria, P.B.S. A simple bund plugging technique for improving water productivity in wetland rice. Soil Tillage Res. 2011, 112, 66-75.

238. Patil, M.D.; Das, B.S. Assessing the effect of puddling on preferential flow processes through under bund area of lowland rice field. Soil Tillage Res. 2013, 134, 61-71.

239. Liu, C.W.; Huang, H.C.; Chen, S.K.; Kuo, Y.M. Subsurface return flow and ground water recharge of terrace fields in northern Taiwan 1. JAWRA J. J. Am. Water Resour. Assoc. 2004, 40, 603-614. [CrossRef]

240. Chen, Z.; Govindaraju, R.S.; Kavvas, M.L. Spatial averaging of unsaturated flow equations under infiltration conditions over areally heterogeneous fields-1. Development of models. Water Resour. Res. 1994, 30, 523-534. [CrossRef]

241. Zhu, Y.; Shi, L.; Lin, L.; Yang, J.; Ye, M. A fully coupled numerical modeling for regional unsaturated-saturated water flow. J. Hydrol. 2012, 475, 188-203. [CrossRef]

242. Liu, C.W.; Chen, S.K.; Jou, S.W.; Kuo, S.F. Estimation of the infiltration rate of a paddy field in Yun-Lin Taiwan. Agric. Syst. 2001, 68, 41-54. [CrossRef]

243. Tournebize, J.; Watanabe, H.; Takagi, K.; Nishimura, T. The development of a coupled model (PCPF-SWMS) to simulate water flow and pollutant transport in Japanese paddy fields. Paddy Water Environ. 2006, 4, 39-51. [CrossRef]

244. Humphreys, E.; Muirhead, W.A.; Fawcett, B.J. The Effect of Puddling and Compaction on Deep Percolation and Rice Yield in Temperate Australia. In Soil and Water Engineering for Paddy Field Management, Proceedings of the International Workshop held at the Asian Institute of Technology, 28-30 January, 1992, Bangkok, Thailand; Murty, V.V.N., Koga, K., Eds.; CSIRO: Canberra, Australia, 1992; pp. 212-219.

245. Kukal, S.S.; Aggarwal, G.C. Percolation losses of water in relation to puddling intensity and depth in a sandy loam rice (Oryza sativa) field. Agric. Water Manag. 2002, 57, 49-59. [CrossRef]

246. Chen, S.K.; Liu, C.W. Analysis of water movement in paddy rice fields (I) experimental studies. J. Hydrol. 2002, 260, 206-215. [CrossRef]

247. Wencai, D.; Fangfei, C.; Qiang, F.; Chengpeng, C.; Xue, M.; Xianye, Y. Effect of soybean roots and a plough pan on the movement of soil water along a profile during rain. Appl. Water Sci. 2019, 9, 138. [CrossRef]

248. Humphreys, E.; Muirhead, W.A.; Fawcett, B.J.; Townsend, J.T.; Murray, E.A. Puddling in Mechanized Rice Culture: Impacts on Water Use and the Productivity of Rice and Post-Rice Crops. In Management of Clay Soils for Rainfed Lowland Rice-based Cropping Systems; ACIAR Proceedings No. 70; Kirchhof, G., So, H.B., Eds.; Australian Centre for International Agricultural Research: Canberra, Australia, 1996; pp. 213-218.

249. Aggarwal, G.C.; Sidhu, A.S.; Sekhon, N.K.; Sandhu, K.S.; Sur, H.S. Puddling and N management effects on crop response in a rice-wheat cropping system. Soil Tillage Res. 1995, 36, 129-139.

250. Sharma, P.K.; Bhagat, R.M. Puddling and compaction effects on water permeability of texturally different soils. J. Indian Soc. Soil Sci. 1993, 41, 1-6.

251. Singh, V.P.; Wichkam, T.H. Water Movement through Wet Soils. In Proceedings of the Symposium on Soils and Rice; IRRI: Los Banos, Phillipines, 1977; Volume 2.

252. Tabbal, D.F.; Lampayan, R.M.; Bhuiyan, S.I. Water Efficient Irrigation Technique for Rice. In Proceedings of the International Workshop on Soil and Water Engineering for Paddy Field Management, Asian Institute of Technology, Bangkok, Thailand, 28-30 January 1992; pp. 146-159.

253. Bouman, B.A.M.; Wopereis, M.C.S.; Kroff, M.J.; Ten Berge, H.F.M.; Tuong, T.P. Water use efficiency of flooded rice fields. (II) Percolation and seepage losses. Agric. Water Manag. 1994, 26, 291-304. [CrossRef]

254. Guerra, L.C.; Bhuiyan, S.I.; Tuong, T.P.; Barker, R. Producing More Paddy with Less Water from Irrigated Systems; SWIM Paper 5 International Water Management Institute (IWMI): Colombo, Sri Lanka, 1998.

255. Sanchez, P. Soil Management in Rice Cultivation. In Properties and Management of Soils in the Tropics; Cambridge University Press: Cambridge, UK, 2019.

256. Greening, A.L.; Greene, L.D.; Difiglio, C. Energy efficiency and consumption-The re-bound effect-A survey. Energy Policy 2000, 28, 389-401. [CrossRef]

257. Caswell, M.; Zilberman, D. The effects of well depth and land quality on the choice of irrigation technology. Am. J. Agric. Econ. 1986, 68, 798-811. [CrossRef]

258. Kemper, K.E. Ground water-From development to management. Hydrogeol. J. 2004, 12, 3-5. [CrossRef] 
259. Burt, C.M.; Clemmens, A.J.; Strelkoff, T.S.; Solomon, K.H.; Bliesner, R.D.; Hardy, L.A.; Howell, T.A.; Eisenhauer, D.E. Irrigation performance measures: Efficiency and uniformity. J. Irrig. Drain. Eng. 1997, 123, 423-442. [CrossRef]

260. Huffaker, R.; Whittlesey, N. Agricultural Water Conservation Legislation: Will It Save Water? Choices 1995, 4, $24-28$.

261. Whittlesey, N.K. Improving Irrigation Efficiency through Technology Adoption: When Will It Conserve Water? In Water Resources Perspectives: Evaluation, Management and Policy; Alsharhan, A.S., Wood, W.W., Eds.; Elsevier Science: Amsterdam, The Netherlands, 2003; pp. 53-62.

262. Pfeiffer, L.; Lin, C.-Y.C. Does efficient irrigation technology lead to reduced groundwater extraction? Empirical evidence. J. Environ. Econ. Manag. 2013, 67, 189-208. [CrossRef]

263. Hu, X.; Shi, L.; Zeng, J.; Yang, J.; Zha, Y.; Yao, Y.; Cao, G. Estimation of actual irrigation amount and its impact on groundwater depletion: A case study in the Hebei Plain, China. J. Hydrol. 2016, 543, 433-449. [CrossRef]

264. Alley, W.M.; Healy, R.W.; LaBaugh, J.W.; Reilly, T.E. Flow and storage in groundwater systems. Science 2002, 296, 1985-1990. [CrossRef]

265. Oki, T.; Kanae, S. Global hydrologic cycles and world water resources. Science 2006, 313, 1068-1072. [CrossRef] [PubMed]

266. Lin, L.; Zhang, Z.B.; Janssen, M.; Lennartz, B. Infiltration properties of paddy fields under intermittent irrigation. Paddy Water Environ. 2014, 12, 17-24. [CrossRef]

267. Matsuno, Y.; Nakamura, K.; Masumoto, T.; Matsui, H.; Kato, T.; Sato, Y. Prospects for multi functionality of paddy rice cultivation in Japan and other countries in monsoon Asia. Paddy Water Environ. 2006, 4, 189-197. [CrossRef]

268. MPO (Master Plan Organization). Groundwater Resources of Bangladesh; Technical Report no 5.; Master Plan Organization: Dhaka, Bangladesh, 1987.

269. Bredehoeft, J.D. The water budget myth revisited: Why hydrogeologists model. Ground Water 2002, 40, 340-345. [CrossRef] [PubMed]

270. Revelle, R.; Lakshminarayana, V. The Ganges water machine. Science 1975, 188, 611-616. [CrossRef] [PubMed]

271. Khan, M.R.; Voss, C.I.; Yu, W.; Michael, H.A. Water resources management in the Ganges Basin: A comparison of three strategies for conjunctive use of groundwater and surface water. Water Resour. Manag. 2014, 28, 1235-1250. [CrossRef]

272. Kiriyama, T.; Ichikawa, T. Preservation of ground water basin recharging by paddy filed. Proc. Hydraul. Eng. 2004, 48, 373-378, (in Japanese with English abstract). [CrossRef]

273. Beecher, H.G.; Hume, I.H.; Dunn, B.W. Improved method for assessing rice soil suitability to restrict recharge. Aust. J. Exp. Agric. 2002, 42, 297-307. [CrossRef]

274. Patle, G.T.; Singh, D.K.; Sarangi, A.; Sahoo, R.N. Modelling of groundwater recharge potential from irrigated paddy field under changing climate. Paddy Water Environ. 2017, 15, 413-423. [CrossRef]

275. Sir MacDonald, Partners Limited. Water Balance Studies Bangladesh; Final Report, Report II Groundwater; Demter House: Station Road, Cambridge, UK, 1983.

276. Harvey, C.F.; Ashfaque, K.N.; Yu, W.; Badruzzaman, A.B.M.; Ali, M.A.; Oates, P.M.; Michael, H.A.; Neumann, R.B.; Beckie, R.; Islam, S.; et al. Groundwater dynamics and arsenic contamination in Bangladesh. Chem. Geol. 2006, 228, 112-136. [CrossRef]

277. Shamsudduha, M.; Taylor, R.G.; Ahmed, K.M.; Zahid, A. The impact of intensive groundwater abstraction on recharge to a shallow regional aquifer system: Evidence from Bangladesh. Hydrogeol. J. 2011, 19, 901-916. [CrossRef]

278. Akhtar, M.R. Impact of resource conservation technologies for sustainability of irrigated agriculture in Punjab-Pakistan. Pak. J. Agric. Res. 2006, 44, 239-255.

279. Sarwar, M.N.; Goheer, M.A. Adoption and Impact of Zero Tillage Technology for Wheat in Rice-Wheat System-Water and Cost Saving Technology. A case study from Pakistan (Punjab). In Proceedings of the International Forum on Water Environmental Governance in Asia, Bangkok, Thailand, 14-15 March 2007.

280. Erenstein, O.; Laxmi, V. Zero tillage impacts in India's rice-wheat systems: A review. Soil Tillage Res. 2008, 100, 1-14.

281. Hobbs, P.R.; Govaerts, B. How Conservation Agriculture Can Contribute to Buffering Climate Change. In Climate Change and Crop Production; Reynolds, M., Ed.; CAB International: Wallingford, UK, 2009.

282. Pathak, H. Greenhouse Gas Mitigation in Rice-Wheat System with Resource Conserving Technologies. In Proceedings of the 4th World Congress on Conservation Agriculture, New Delhi, India, 4-7 February 2009.

283. Garg, K.K.; Das, B.S.; Safeeq, M.; Bhadoria, P.B. Measurement and modeling of soil water regime in a lowland paddy field showing preferential transport. Agric. Water Manag. 2009, 96, 1705-1714. [CrossRef]

284. Törnqvist, R.; Jarsjö, J. Water savings through improved irrigation techniques: Basin-scale quantification in semi-arid environments. Water Resour. Manag. 2012, 26, 949-962. [CrossRef]

285. Elhassan, A.M.; Goto, A.; Mizutani, M. Combining a tank model with a groundwater model for simulating regional groundwater flow in an alluvial fan. Trans. JSIDRE 2001, 215, 21-29.

286. Chen, S.K.; Liu, C.W.; Huang, H.C. Analysis of water movement in paddy rice fields (II) simulation studies. J. Hydrol. 2002, 268, 259-271. [CrossRef]

287. Anan, M.; Yuge, K.; Nakano, Y.; Saptomo, S.; Haraguchi, T. Quantification of the effect of rice paddy area changes on recharging groundwater. Paddy Water Environ. 2007, 5, 41-47. [CrossRef]

288. Iwasaki, Y.; Nakamura, K.; Horino, H.; Kawashima, S. Assessment of factors influencing groundwater-level change using groundwater flow simulation, considering vertical infiltration from rice-planted and crop-rotated paddy fields in Japan. Hydrogeol. J. 2014, 22, 1841-1855. [CrossRef] 
289. Riasat, A.; Mallants, D.; Walker, G.; Silberstein, R. A review of groundwater recharge under irrigated agriculture in Australia. In Proceedings of the EGU General Assembly Conference Abstracts, Vienna, Austria, 27 April-2 May 2014.

290. Walker, G.R.; Currie, D.; Smith, T. Modelling recharge from irrigation developments with a perched water table and deep unsaturated zone. Water 2020, 12, 944. [CrossRef]

291. Peña-Arancibia, J.L.; Mainuddin, M.; Ahmad, G.R.; Hodgson, G.; Murad, K.F.I.; Ticehurst, C. Groundwater use and rapid irrigation expansion in a changing climate: Hydrological drivers in one of the world's food bowls. J. Hydrol. 2020, 581, 124300. [CrossRef]

292. Kumar, K.; Gupta, S.K. Decline of groundwater tables in the upper Yamuna basin: Causes and management strategies. Irrig. Drain. 2010, 59, 606-620. [CrossRef]

293. Xu, X.; Huang, G.; Qu, Z.; Pereira, L.S. Assessing the groundwater dynamics and impacts of water saving in the Hetao Irrigation District, Yellow River basin. Agric. Water Manag. 2010, 98, 301-313. [CrossRef]

294. Mustafa, T.M.S.; Shamsudduha, M.; Huysmans, M. Effect of Irrigation Return Flow on Groundwater Recharge in an Overexploited Aquifer in Bangladesh. In Proceedings of the EGU General Assembly Conference Abstracts, Vienna, Austria, 17-24 April 2016.

295. Ren, D.Y.; Xu, X.; Hao, Y.Y.; Huang, G.H. Modeling and assessing field irrigation water use in a canal system of Hetao, upper Yellow River basin: Application to maize, sunflower and watermelon. J. Hydrol. 2016, 532, 122-139. [CrossRef]

296. Humphreys, E.; Gaydon, D.S. Options for increasing the productivity of the rice-wheat system of North-West India while reducing groundwater depletion. Part 2. Is conservation agriculture the answer? Field Crops Res. 2015, 173, 81-94.

297. Dillon, P.J.; Escalante, E.F.; Tuinhof, A. Management of aquifer recharge and discharge processes and aquifer storage equilibrium. In GEF-FAO Groundwater Governance Thematic Paper 4: Groundwater Governance-A Global Framework for Action; Global Environment Facility (GEF): Washington, DC, USA, 2012.

298. Frederiksen, H.D.; Allen, R.G. A common basis for analysis, evaluation and comparison of off stream water uses. Water Int. 2011, 36, 266-282. [CrossRef]

299. Khan, S.; Blackwell, J.; Rana, T.; Beddek, R. What are the Options for Managing Extreme Climate Variability in Australian Catchments? In Catchment Companions Growing Together. Proceedings of the 50th ANCID National Irrigation Conference, Shepparton, VIC, Australia, 19-22 October 2003; Australian National Committee on Irrigation and Drainage: Shepparton, Australia, 2003.

300. Duvert, C.; Jourde, H.; Raiber, M.; Cox, M.E. Correlation and spectral analyses to assess the response of a shallow aquifer to low and high frequency rainfall fluctuations. J. Hydrol. 2015, 527, 894-907. [CrossRef]

301. Alley, W.M.; Leake, S.A. The journey from safe yield to sustainability. Ground Water 2004, 42, 12-16. [CrossRef] [PubMed]

302. Foster, S.; Perry, C.; Hirata, R.; Garduno, H. Groundwater Resource Accounting: Critical for Effective Management in a 'Changing World; The World Bank: Washington, DC, USA, 2009; Volume 51785, pp. 1-12.

303. Narayana, P.; Scott, C. Effectiveness of legislative controls on groundwater extraction. In Proceedings of the Third IWMI-Tata Annual Water Policy Workshop, Anand, India, 17-19 February 2004.

304. Shah, T. Taming the Anarchy: Groundwater Governance in South Asia; RFF Press: Washington, DC, USA, 2009.

305. Salem, G.S.A.; Kazama, S.; Komori, D.; Shahid, S.; Dey, N.C. Optimum abstraction of groundwater for sustaining groundwater level and reducing irrigation cost. Water Resour. Manag. 2017, 31, 1947-1959. [CrossRef]

306. MOA; FAO. Master Plan for Agricultural Development in the Southern Region of Bangladesh; Ministry of Agriculture (MoA, Government of Bangladesh of Bangladesh) and United Nations Food and Agriculture Organization: Dhaka, Bangladesh, $2013 ;$ p. 104.

307. Bell, A.R.; Bryam, E.; Ringler, C.; Ahmed, A.U. Rice productivity in Bangladesh: What are the benefits of irrigation? Land Use Policy 2015, 48, 1-12. [CrossRef]

308. Bernier, Q.; Sultana, P.; Bell, A.R.; Ringler, C. Water management and livelihood choices in southwestern Bangladesh. J. Rural Stud. 2016, 45, 134-145. [CrossRef]

309. Ambast, S.K.; Tyagi, N.K.; Raul, S.K. Management of declining groundwater in the Trans Indo-Gangetic Plain (India): Some options. Agric. Water Manag. 2006, 82, 279-296. [CrossRef]

310. Moulds, S.; O'Keeffe, J.I.M.M.Y.; Buytaert, W.; Mijic, A. Climate Change Impacts on the Water Resources of the Ganges Basin; Grantham Institute Briefing Note 6: London, UK, 2017.

311. Kirby, J.M.; Ahmad, M.D.; Mainuddin, M.; Palash, W.; Quadir, M.E.; Shah-Newaz, S.M.; Hossain, M.M. The impact of irrigation development on regional groundwater resources in Bangladesh. Agric. Water Manag. 2015, 159, 264-276. [CrossRef] 